\title{
GEOCHEMICAL AND MINERALOGICAL FINGERPRINTS OF THE SEDIMENTS SUPPLY AND EARLY DIAGENETIC PROCESSES IN THE BIZERTE LAGOON (TUNISIA)
}

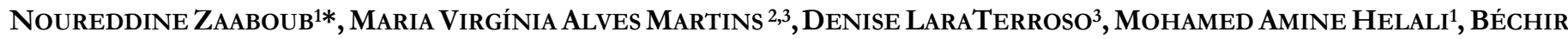

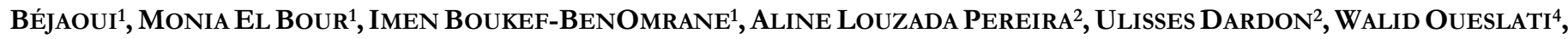 \\ RYM ENNOURI ${ }^{1}$, FRANCOIS GALGANI ${ }^{5}$, EdUARDo FERREIRA DA SILVA ${ }^{3}$, FERNANDo ROCHA ${ }^{3}$ AND LOTFI ALEYA $^{6}$
}

1 Laboratoire du Milieu Marin, Institut National des Sciences et Technologies de la Mer, 2025 Salammbô, Tunisia. nouri_zaaboub@yahoo.fr, he.amine@gmail.com, bejaoui.bechir@instm.rnrt.tn,monia.elbour@instm.rnrt.tn, imen.boukef@yahoo.fr, rymenvmarin@yahoo.fr

2 Laboratório de Micropaleontologia (LMP-UERJ), Universidade do Estado do Rio de Janeiro - UERJ, Faculdade de Geologia, Departamento de Estratigrafia e Paleontologia. Av. São Francisco Xavier, 524, sala 4037F, Maracanã, 20550-013 Rio de Janeiro, RJ, Brazil.virginia.martins@ua.pt, alinelouzadapereira@gmail.com, dardonnn@gmail.com

3 Unidade de Investigação GeoBioTec, Departamento de Geociências, Universidade de Aveiro, Campus de Santiago, $3810-193$ Aveiro, Portugal.laraterroso@ua.pt, eafsilva@ua.pt, tavares.rocha@ua.pt

4 Laboratoire des Ressources Minérales et Environnement, Département de Géologie, Faculté des Sciences de Tunis. Université TunisEl Manar, 2092, Tunisia. w.oueslati@gmail.com

5 IFREMER, LER/PAC, Immeuble Agostini, ZI Furiani, 20600, Bastia, France. francois.galgani@ifremer.fr

6 Université de Bourgogne Franche-Comté, Laboratoire de Chrono-Environnement, UMR CNRS 6249, La Bouloie, F-25030 Besançon Cedex, France. lotfi.aleya@univ-fcomte.fr

*Corresponding AUthor, nouri_zaaboub@yahoo.fr

Received on 5 November 2016

Received in revised form on 10 December 2016

Accepted on 15 December 2016

Editor:

Fabrizio Frontalini, Università degli Studi di Urbino "Carlo Bo", Urbino, Italy
Citation:

Zaaboub, N., Martins, M.V.A., Terroso, D., Helali, M.A., Béjaoui, B., El Bour, M., Boukef-BenOmrane, I., Pereira, A.L., Dardon, U., Oueslati, W., Ennouri, R., Galgani, F., Ferreira da Silva, E., Rocha, F., Aleya, L., 2016. Geochemical and mineralogical fingerprints of the sediments supply and early diagenetic processes in the Bizerte Lagoon (Tunisia). Journal of Sedimentary Environments, 1(4): 432-448.

\section{Abstract}

The Bizerte Lagoon (Tunisia) functions as a sedimentation environment characterized by receiving allochthonous sediments mainly transported by the Ben Hassine, Rharek and Guenich streams, as well as marine sediments from the Mediterranean Sea. It is subjected to significant environmental changes due to the natural and anthropic influences altering the natural patterns of circulation, extraction and/or deposition of mineralogical materials. The aim of this investigation is to analyze the sediments supply and early diagenetic processes in Bizerte Lagoon. The physicochemical parameter of the sediment pore water, as well as their texture, mineralogical composition (X-Ray diffraction technique - XRD), magnetic susceptibility and their geochemical composition (namely lithogenic and biogenic chemical elements analyzed by ICP-MS) were analyzed in 10 sampling stations.
The water temperature with an average of $15.2^{\circ} \mathrm{C}$ was stable in the study area. The sediments were generally characterized by fine granulometry, mainly mud and sandy mud, poorly to very poorly sorted, and constituted by two or more granulometric particle modes. The mineralogical results revealed the presence of phyllosilicates, quartz, pyrite, calcite, anatase and K-feldspar, and other minerals in smaller proportions. The fine sediment and high phyllosilicates and $\mathrm{Al}$ contents indicate the presence of weak currents in most part of the studied area. The results of sorting, skewness and kurtosis suggest that the currents are more active in the northern region of the lagoon, near the channel of communication with the Mediterranean Sea. They also evidence a coarser particle contribution of the Ben Hassine stream to the lagoon. The other streams seem to introduce mostly fine-grained sediments in the lagoon. The currents 
circulation, the water residence time and the biological productivity influence the mineralogical and geochemical characteristics of the bottom sediments. The industrial activity is also an important factor, since it results in the accumulation of high levels of some metals, such as Fe. Metals are mostly retained in the sediment in areas with active biogeochemical activity due to high organic matter accumulation. Mineralogical and geochemical patterns

\section{Introduction}

The sedimentary processes act on preexisting igneous, metamorphic and sedimentary rocks with mechanical and chemical (weathering), erosion and transport, deposition and lithification of fragments (blocks, pebbles) and particles (sand, silt and clay) of these rocks in continental, transitional and marine sedimentary environments (Boggs, 2006, 2009). Sedimentary rocks also include materials derived from biological activities and chemical precipitation (Adamovič, 2009; James and Jones, 2015). The criteria for classification of sedimentary rocks follow several principles, commonly combining aspects such as the environment, sedimentation type, mineralogical constitution and/or particle size (Boggs, 2006, 2009).

Depending on the type, sediments can be classified into clastic, chemical and biological (Pettijohn et al., 1987). The clastic sediments are constituted by disaggregated fragments of several pre-existing rocks (volcanic, metamorphic or even sedimentary) that are transported to other regions and deposited in layers (Boggs, 2006, 2009). The chemical sediments are those originated from the precipitation of solutes, due to the decrease of the solubility or the evaporation of the water (evaporites; Button, 1982). The chemical sediments formed by decreasing the solubility are more commonly the carbonates, which precipitate due to the increase in temperature and the consequent release of carbon dioxide, responsible for the solubility of carbonates (Dean et al., 1975; Dean, 1982; Dean and Fouch, 1983; Tucker and Wright, 1990). Biological sediments are formed by the transformation of excretions and debris (tests, exoand endo- skeletons, shells and so on) of living beings, plants and animals (Pettijohn et al., 1987; Tucker, 2003).

The Bizerte Lagoon functions as a sedimentation basin for instance for the Ben Hassine, Rharek and Guenich Streams as wee as the Tinja Channel and Mediterranean Sea (Béjaoui et al., 2008). This lagoon also serves as a deposit for municipal and industrial effluents and water runoff from agricultural lands (Fertouna-Bellakhal et al., 2014; Barhoumi et al., 2016).

The Bizerte Lagoon is subject to significant environmental changes due to the natural and anthropic activities related for instance to the extraction and/or deposition of mineralogical materials which change the natural patterns of circulation (Jamila et al., 2016). Exploitation of biological products as well as pollution of indicate contributions from different rocks sources, diverse processes of transport and deposition of sediments and varied processes of production of autochthonous materials.

Keywords: Mediterranean coastal lagoon. Allochthonous sediments. Autochthonous sediments. Circulation. Multiproxy approach. Bizerte Lagoon.

water and sediments are the main causes of environmental degradation of this lagoon, as sediments generally retain pollutants for a longer period than water. Only the eastern area of the lagoon is influenced by the water renewal shorter time which favor a longer residence period and greater confinement, thus favoring more anoxic conditions in most part of the lagoon (Zaaboub et al., 2015).

\subsection{Main objectives of the work}

This work intends to contribute to the study of the composition of the superficial sediments of the Bizerte Lagoon, mainly in textural, mineralogical and geochemical terms. It also intends to identify differences in sediment origin as a function of the streams that flow into the Bizerte Lagoon and the pattern of tidal currents.

\section{Study area}

The Bizerte Lagoon is a transitional Mediterranean ecosystem located in Northeast Tunisia at a latitude of $37^{\circ} 08^{\prime}-37^{\circ} 14^{\prime} \mathrm{N}$ and longitude of $9^{\circ} 46^{\prime}-9^{\circ} 56^{\prime} \mathrm{E}$ (Fig. 1). It has a costal elliptical form with an area of ca. $150 \mathrm{~km}^{2}$ with an average depth of $7 \mathrm{~m}$. Its northeast end communicates with the Mediterranean Sea through a channel $(5 \mathrm{~km}$ length; $300 \mathrm{~m}$ width) that empties to the sea via an artificial canal (1500 m length; $140 \mathrm{~m}$ width; $12 \mathrm{~m}$ depth; Fig. 1). This connection allows the entrance of saline water in the lagoon. Its west side interconnects with Ichkeul Lake through the Tinja Channel (length $5 \mathrm{~km}, 300 \mathrm{~m}$ wide and $12 \mathrm{~m}$ deep), which discharges fresh-water into the lagoon (Ben Ismail et al., 2012). Located further south of the lagoon, the Ben Hassine, Rharek and Guenich streams, whose flows depend on precipitation, are also responsible for introducing freshwater into the lagoon.

The Bizerte Lagoon occupies the geological depression in an ante-Neogene solid mass ploughed up and eroded since the late Miocene (Burollet, 1951). In northwest and southwest portions of the lagoon, on the level of Jebel Kchabta outcrop Triassic series (Crampon, 1971). In the southwest portion of the Bizerte Lagoon, Pliocene rocks also outcrop on the level of Jebel Messeftine (Ouakad, 1982). The current coastal morphology of the lagoon results from several sedimentary phases that have occurred since the 
Miocene, and which have continued with variable intensity until present days (Garali et al., 2013).

The region is characterized by a humid subtropical climate with 600 to $800 \mathrm{~mm}$ of annual precipitation (Kallel, 1989). The rainy season coincides with winter, from November to April, with maximum rainfall in February $(219.5 \mathrm{~mm})$, while summer and the rest of the year are dry, with no freshwater inflow from neighboring streams (Garali et al., 2011). The seasonal gradient of water salinity in the Bizerte Lagoon is relatively large, varying on average from 20 in winter to 40 in summer (Afli et al., 2008). In addition, this region has a mountainous relief, occupied by the Atlas
Mountains, a hot and dry central plain and semi-arid areas to the south that merge with the Sahara Desert. In winter, due to increased rainfall, a greater vertical mixing in the lagoon water column occurs. This is also due to the greater amount of freshwater inflow from Ichkeul Lake through the Tinja Channel and also of the Ben Hassine, Rharek and Guenich streams (Fertouna-Bellakhal et al., 2014). On the other hand, in summer there is a greater influence of saline water and temperature increases, promoting a stratification in the water column (Sakka Hlaili et al., 2003). These seasonal changes influence the sediment flow and its internal deposition in the lagoon (Sakka Hlaili et al., 2008).

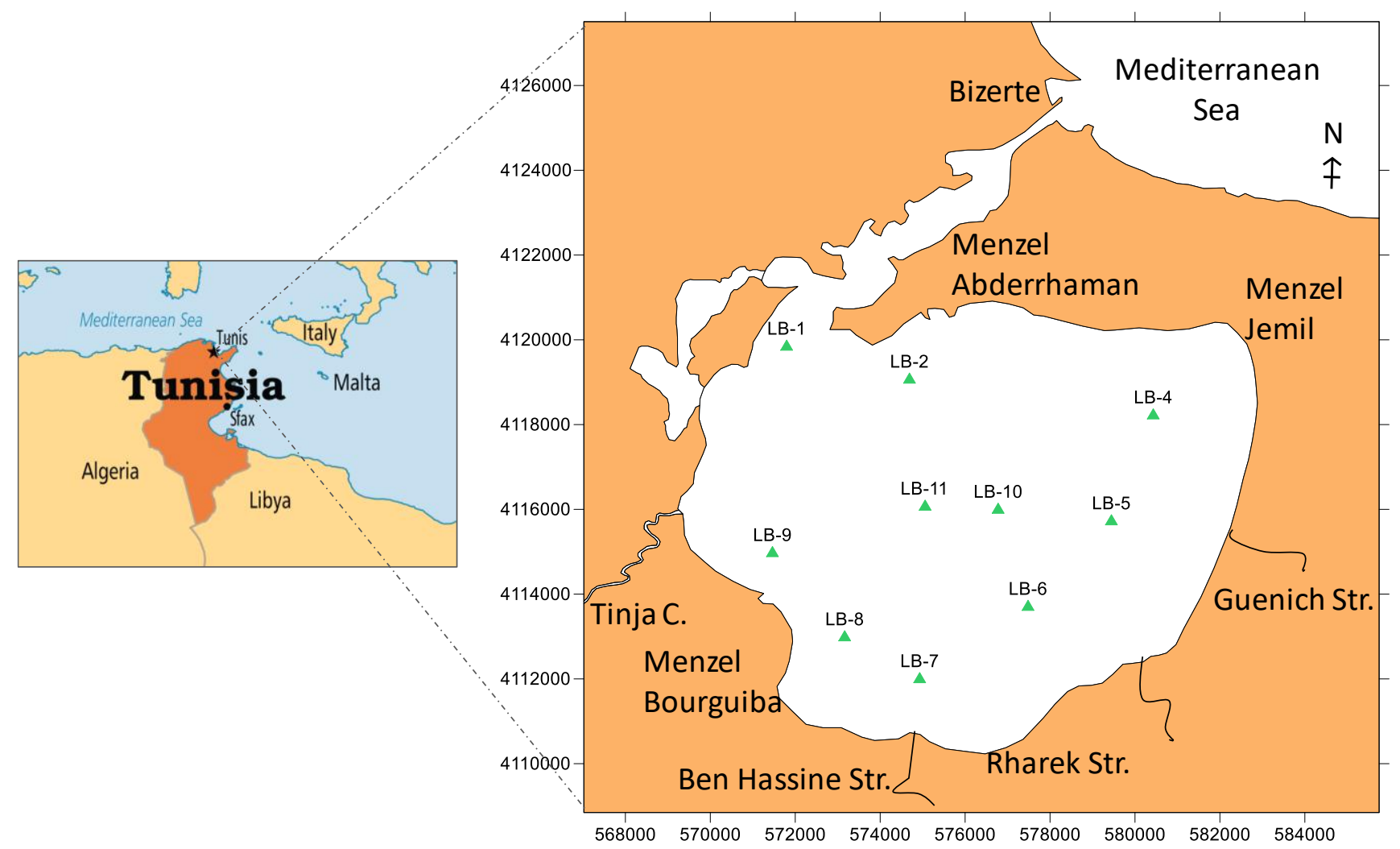

Fig. 1. Location of the studied stations in the Bizerte Lagoon (Tunisia), located in North Africa, close to Tunis. The main cities and streams are indicated. Legend C. - Channel; Str. - Stream.

The hydrodynamics of the lagoon is driven mainly by the wind force, which induces seasonal changes in the circulation, and by tidal currents (Béjaoui et al., 2008). The tidal currents are stronger in the Northern margin and near the entrance channel (INSTM, 2002), decreasing considerably in the interior of the lagoon (Béjaoui et al., 2016). The Bizerte Lagoon has a complex configuration formed by a marine zone, where the port activity is intense, as well as densely populated areas such as at Menzel Abderahman, Menzel Jemil and Menzel Bourguiba cities, being affected by municipal and industrial effluents and water runoff of agricultural land (Fertouna-Bellakhal et al., 2014).
The most important industrial activities are in the vicinity of Bizerte (cement and metal treatment plant), Menzel Jemil (paints and metallurgy) and Menzel Bourguiba cities (with naval port, steelworks, military arsenal and metallurgy; Essid and Aissa, 2002; Garali et al., 2011).

Aquaculture of Mytilus galloprovincialis and other bivalves such as oysters (Afli et al., 2008) also contributes to the increase of the organic matter flow and the establishment of anoxic conditions at the bottom of the lagoon and promotes the accumulation of pollutants in sediments (Zaaboub et al., 2015). 


\section{Materials and methods}

This work is based on the study of sediments collected in March 2013 in 10 sampling stations georeferenced with a GPS, in the Bizerte Lagoon (Tunisia, Fig. 1), the same stations studied by Martins et al. (2015a, 2016). This work reanalyzes some selected data obtained by these authors and new geochemical data, namely lithogenic and biogenic chemical elements.

Sampling was performed with a box corer, between $7 \mathrm{~m}$ and $12 \mathrm{~m}$ depth. At each sampling station more than three independent deployment of a box corer was used to obtain sediment for textural, geochemical and mineralogical analyses.

Only the first centimeter of sediment was collected in each site. At each sampling station, physicochemical parameters were measured in the sediment pore water, such as temperature $\left({ }^{\circ} \mathrm{C}\right), \mathrm{pH}$ and redox potential $(\mathrm{Eh} ; \mathrm{mV})$. The sediment samples were stored in properly identified plastic containers and cold preserved. Once in the laboratory, sediments were prepared for the textural, mineralogical and geochemical analyses. The magnetic susceptibility of the sediment was also measured in the total sediment with a portable KT-9 Digital Magnetic Susceptibility Meter.

The textural data were obtained with a laser microgranulometer (Malvern Mastersize) after removing the coarser sediment fraction $(>1000 \mu \mathrm{m}$, which is composed mostly by fragments of mollusk shells and remnants of organic matter from continental sources). The mineralogy was determined by X-Ray Diffraction methods (XRD) and the geochemical analysis by ICP-MS after total digestion of the sediment.

The geochemical analysis includes the concentrations of (Al, Ba, Ca, Fe, Hf, K, Li, Mn, Mg, Na, Nb, P, S, Sr, Ta and $\mathrm{Zr})$. Both analyses were performed in the fine fraction. The detailed description of the procedures applied in the sediment analyses is found in Martins et al. (2015a, 2016). Total organic matter (TOC) content was determined with a Leco equipment. The TOC contents were analyzed with a Perkin Elmer (Waltham, MA, USA) PE 2400 CHN system.

\subsection{Statistical Analyses}

Data selected for their relevance to this work (physicochemical, textural, mineralogical and geochemical) were statistically analyzed after being transformed by log $(x+1)$. An R-mode cluster analysis to compare the distribution of the selected variables with the use of 1 Pearson R correlations was performed. For the grouping of variables, the complete linkage method was used. The same variables were also considered for the Q-mode cluster analysis to group stations with similar sedimentological characteristics by using the Euclidian distances and the
Ward's method for grouping of stations. The statistical analyses were carried out with the Statistica 12 software. The maps were performed with the Surfer 10 software (datum WGS84).

\section{Results}

\subsection{Physicochemical parameters of sediment pore water}

The physicochemical parameters measured in the surface sediment pore water (Appendix 1) exhibit the following ranges: temperature $14.7-15.8^{\circ} \mathrm{C}$ (mean $15.2^{\circ} \mathrm{C}$ ), $\mathrm{pH} 7.7-8.2$ (mean 8.0) and $\mathrm{Eh}-30.0 \mathrm{mV}$ and $-57.2 \mathrm{mV}$ (mean $-43.8 \mathrm{mV}$ ). The temperature is slightly variable in the study area. The Eh values are commonly negative, but significantly decrease in the LB11 station located in the center of the lagoon. The lowest $\mathrm{pH}$ value is recorded in the station LB9.

\subsection{Sediment texture and TOC}

The textural data are reported in Figure 2 and Appendix 1. The sediments are, in general, composed by mud and sandy mud, with a sediment mean grain size (SMGS) varying between $7 \mu \mathrm{m}$ and $23 \mu \mathrm{m}$ (Fig. 2A). The sediments are poorly to very poorly sorted, consisting of bimodal to polymodal particles. The coarser sediments are located at the entrance of the lagoon (LB1 and LB2 stations) and in the south zone, LB7 station located in front of the mouth of the Ben Hassine stream (Fig. 2A). High sorting (Fig. 2B), skewness and kurtosis values (Appendix 1) are recorded in these stations corresponding to: poorly and very poorly sorted sediments; and very coarse skewed to approximately symmetric; and mesokurtic to platykurtic sediments (Appendix 1). In the LB1, LB2 and LB7 stations, very poorly sorted, mesokurtic and coarse skewed to very coarse skewed sediments are found (Appendix 1). In the other stations, sediments are poorly sorted, symmetrical and platykurtic (Appendix 1).

Clay fraction content increases mostly in the center and western side of the lagoon (Fig. 2C). TOC content varies between $2.5 \%$ and $5.9 \%$ (mean $4.2 \%$ ) in the study area. The highest values are recorded in the northern and eastern sector of the lagoon (Fig. 2D).

\subsection{Mineralogical composition of the sediments and magnetic susceptibility}

The main mineralogical results are presented in the maps of distribution in Figure 3. The main sedimentary minerals are phyllosilicates (15.1-61.9\%; mean 42.4\%; Fig. 3A), quartz (9.4-60.4\%; mean $18.1 \%$; Fig. 3B), pyrite $(0.2-14.6 \%$; mean 2.6\%; Fig. 3C), calcite (12.5-40.3\%; mean 26.4\%; Fig. 3D), anatase $(<10.2 \%$; mean $2.7 \%$; Fig. 3E) and K-feldspars $(1.3-5.0 \%$; mean $2.4 \%$; Fig. 3F). 

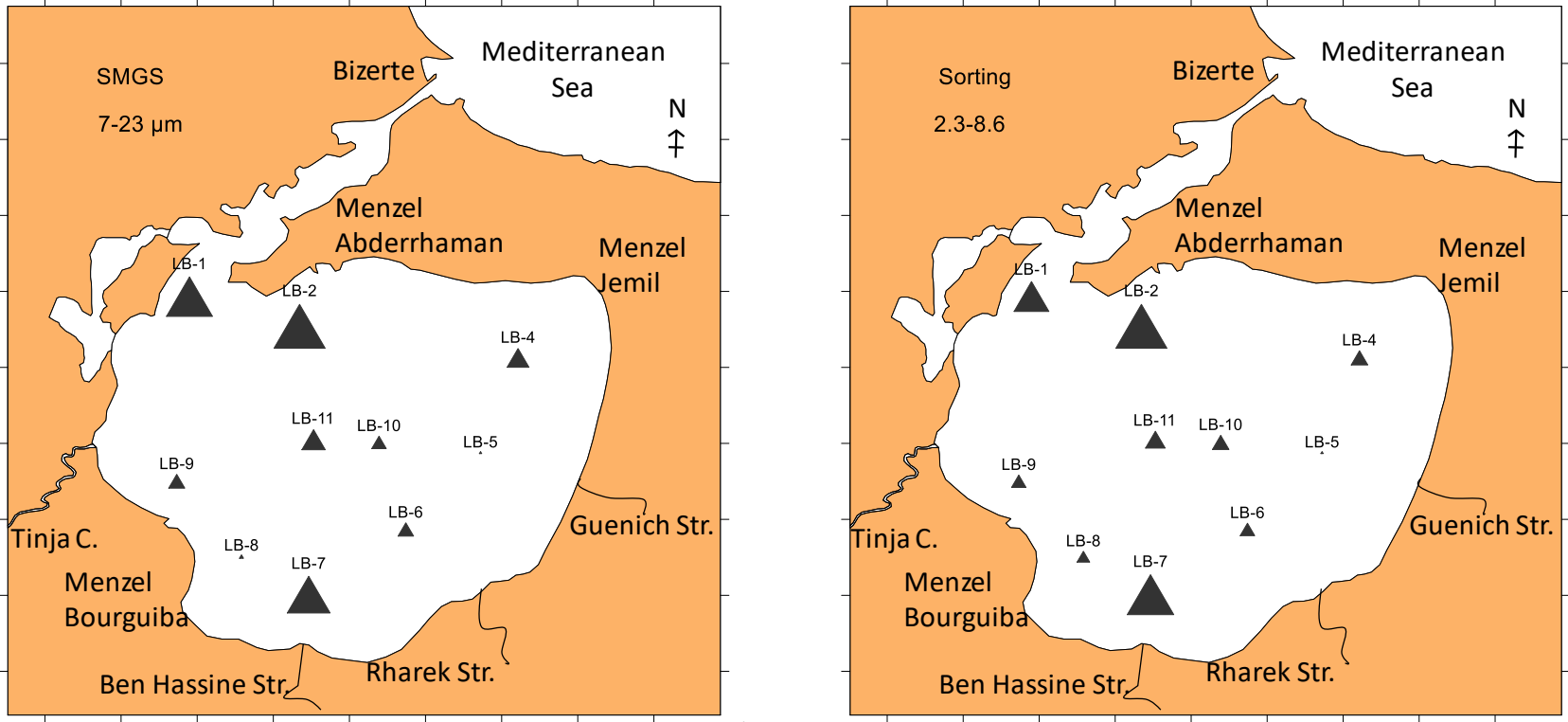

A
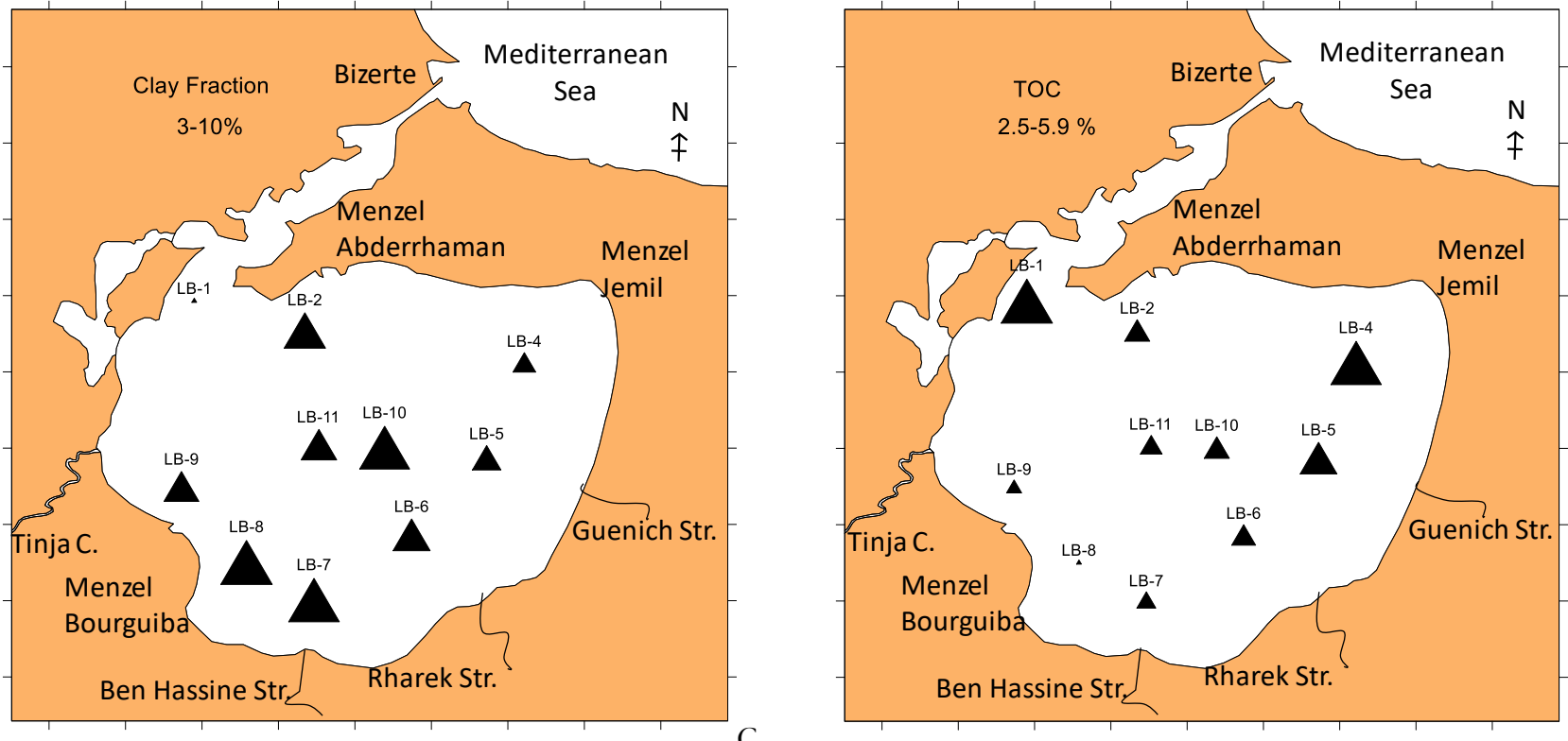

Fig. 2. Distribution maps of the following variables: A) sediment mean grain size (SMGS; $\mu \mathrm{m})$. B) Sorting; C) Clay Fraction (\%); D) TOC $(\%)$. The main cities and streams are indicated. Legend C. - Channel; Str. - Stream.

The sediments also present smaller proportions of other minerals, such as plagioclase ( $<4 \%$; mean $0.8 \%$; Fig. $3 \mathrm{G})$, siderite $(<2.1$; mean $0.8 \%$; Fig. $3 \mathrm{H})$, berthierine ferrous $(0.2-$ $3.4 \%$; mean $1.6 \%$; Fig. 3I), anhydrite $(<4.6 \%$; mean $1.6 \%$; Fig. 3I Phyllosilicates are abundant in all stations except in LB11 (center of the lagoon), where a high quartz content is found. Some minerals such as calcite, K-feldspars, berthierine ferrous and phyllosilicates have similar pattern of distribution. Anatase has a distribution pattern similar to that of quartz. The highest concentration of pyrite is found in
LB10 and the lowest in LB11 in the center of the lagoon. Plagioclase is relatively abundant near Rharek and Guenich streams' mouths.

The values of siderite rise slightly on the margins of the lagoon, except in LB6 and LB7 stations, located in front of the mouth of the Ben Hassine and Rharek streams, respectively. Magnetic susceptibility values range from -0.13 to $-0.29 \mathrm{SI}$ (mean $-0.21 \mathrm{SI}$ ); the lowest values are recorded in LB4 and LB10 stations and the highest in LB2 station (Appendix 1). 


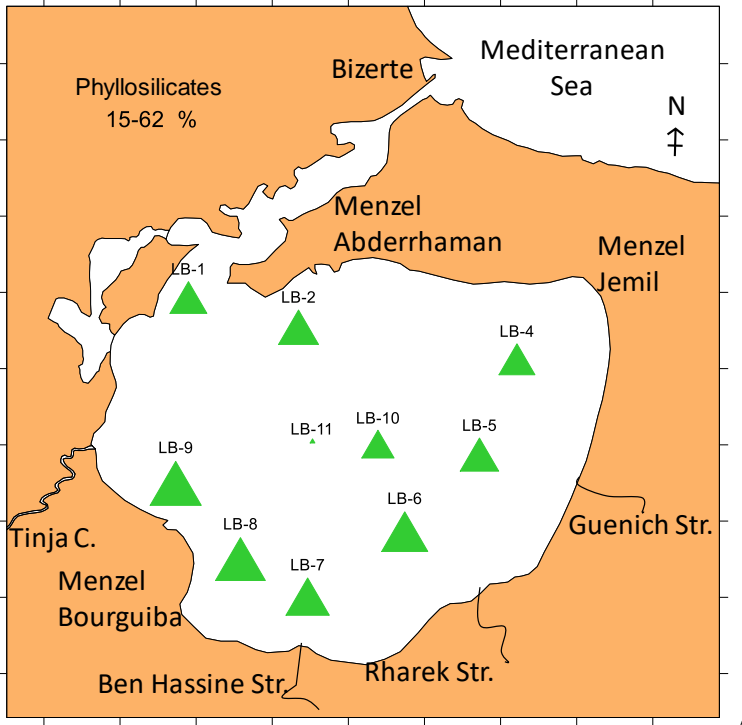

A

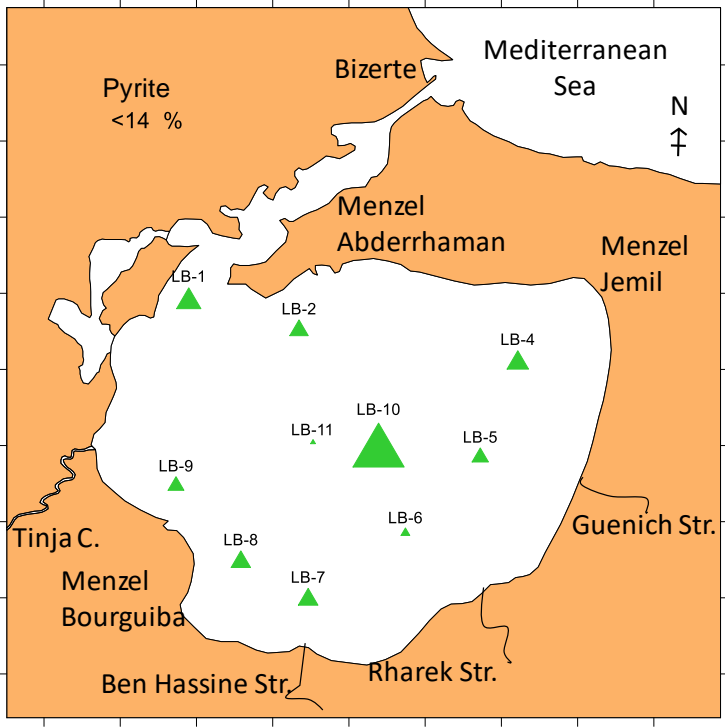

C

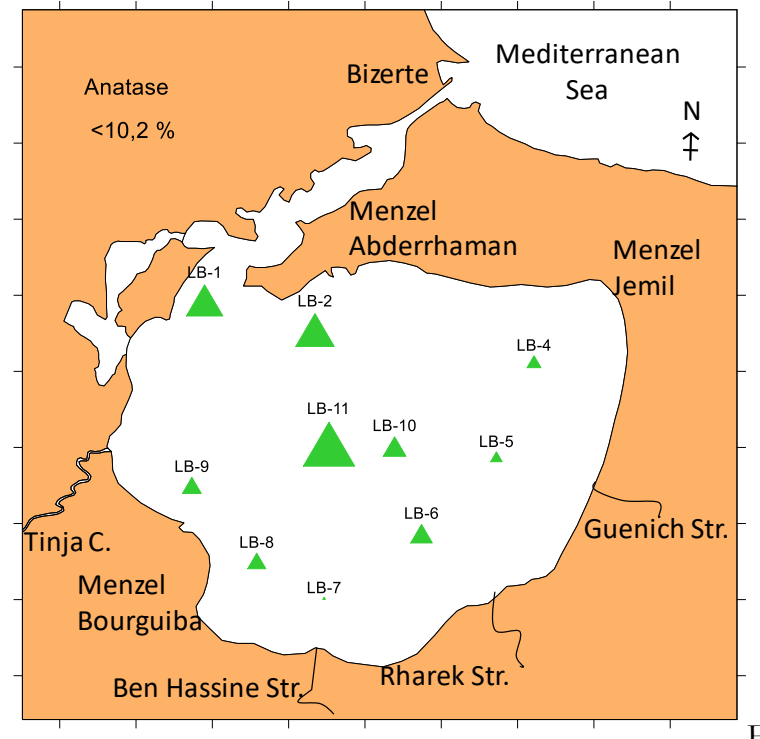

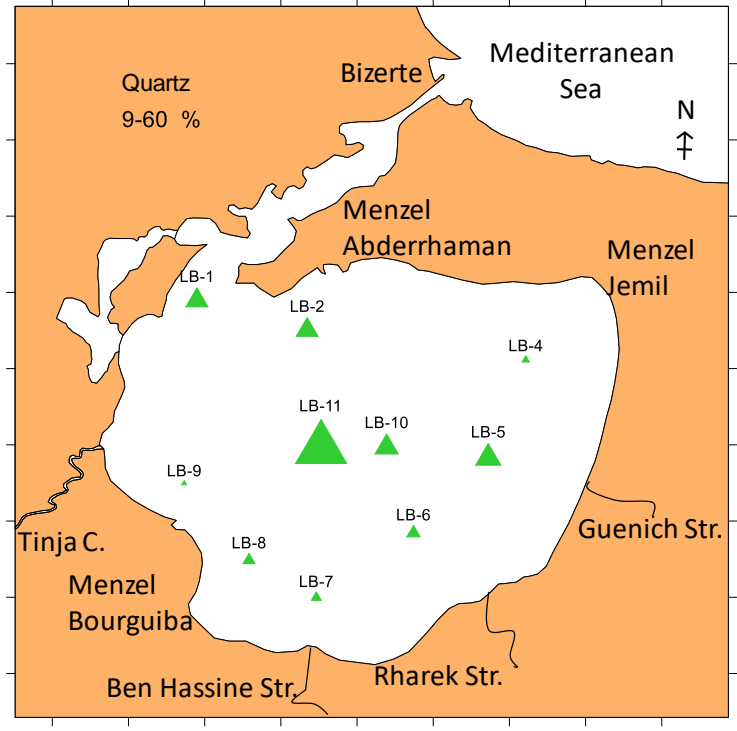

B

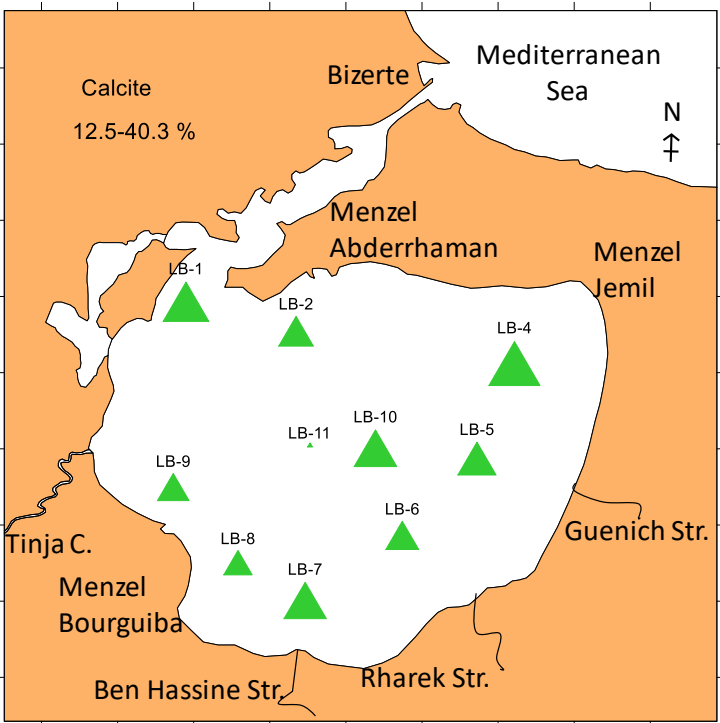

$\mathrm{D}$

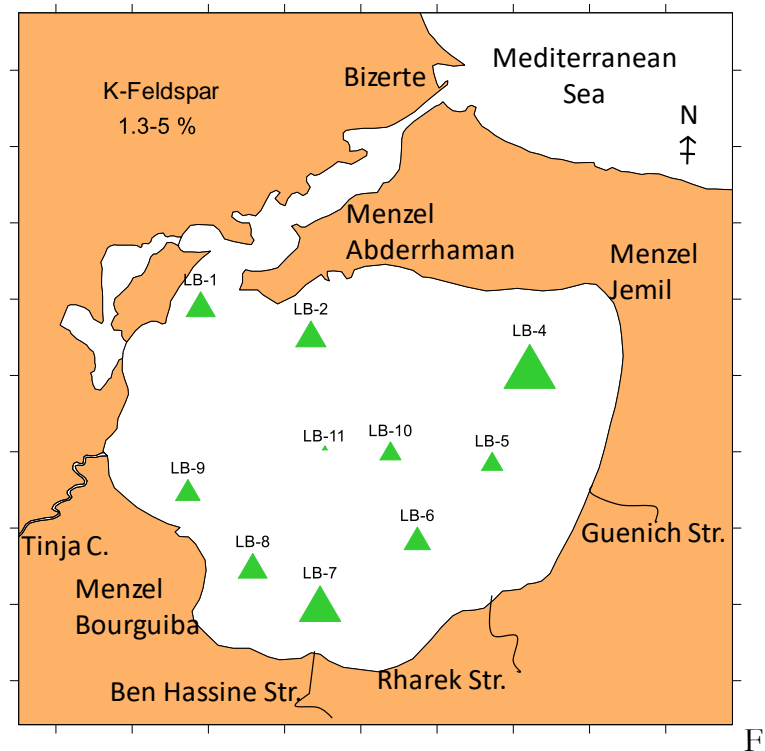

Fig. 3. Distribution maps of the percentage (\%) of sedimentary minerals in the studied stations: A) Phyllosilicates; B) Quartz; C) Pyrite; D) Calcite; E) Anatase; F) K-Feldspars. The main cities and streams are indicated. Legend C. - Channel; Str. - Stream. 

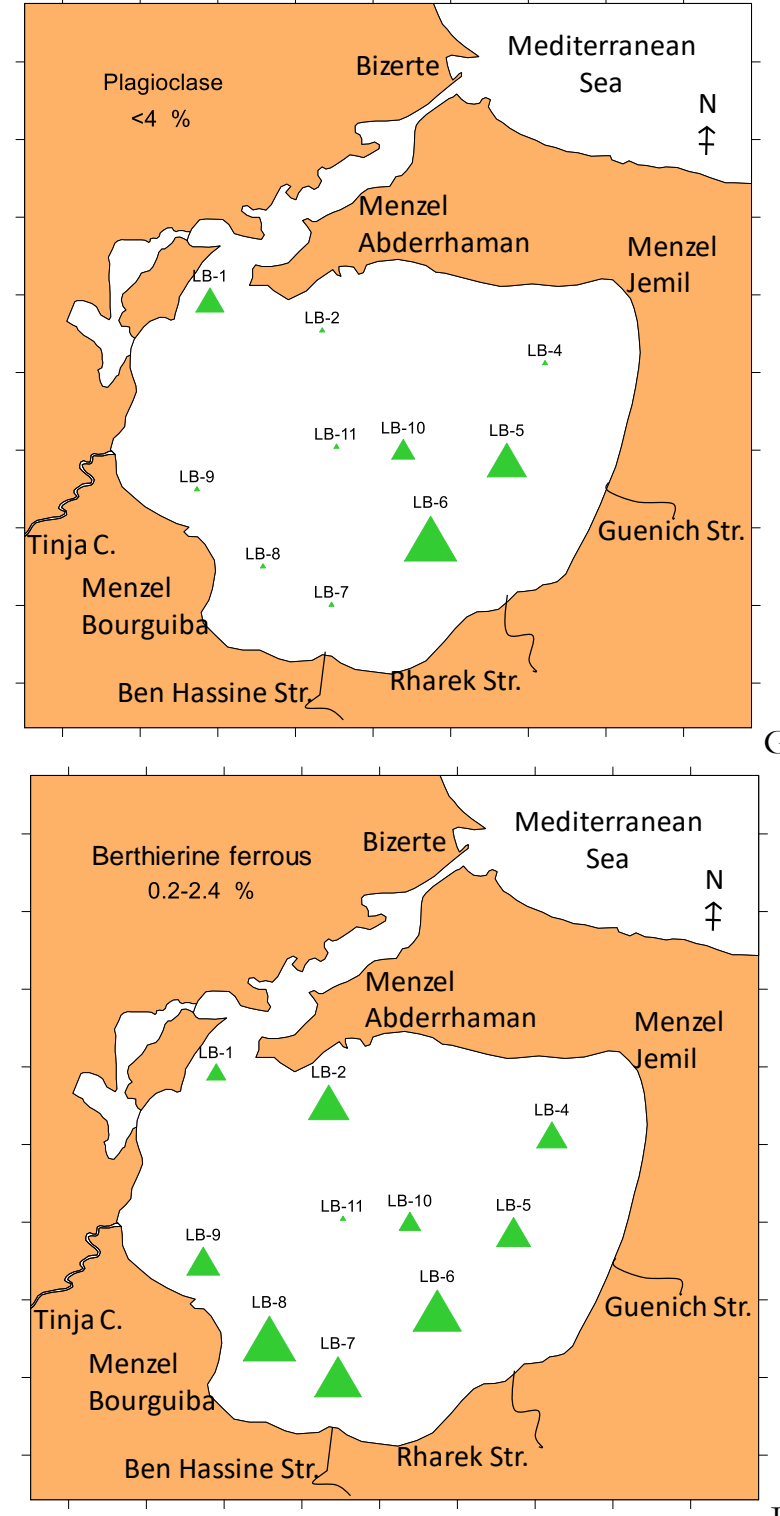

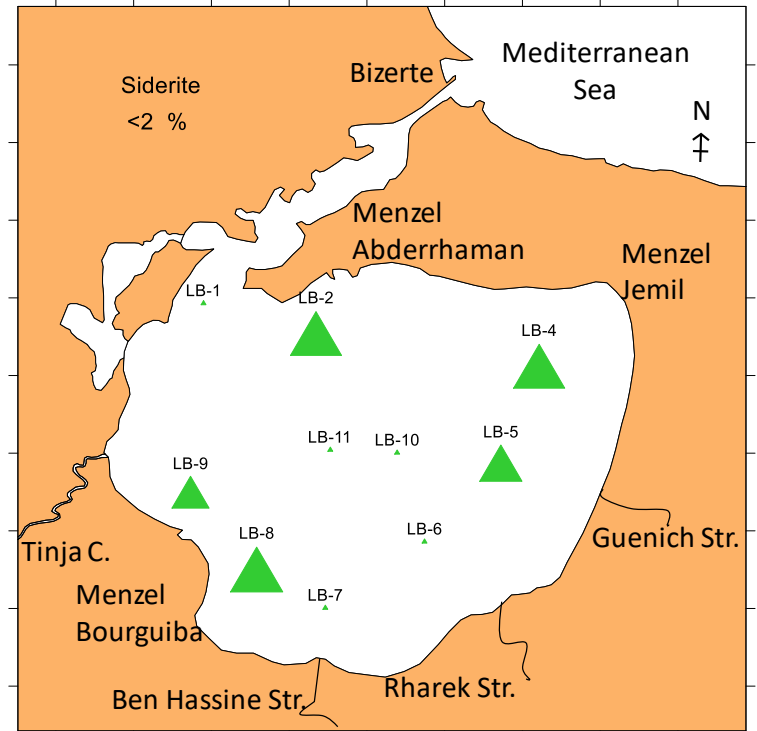

$\mathrm{H}$

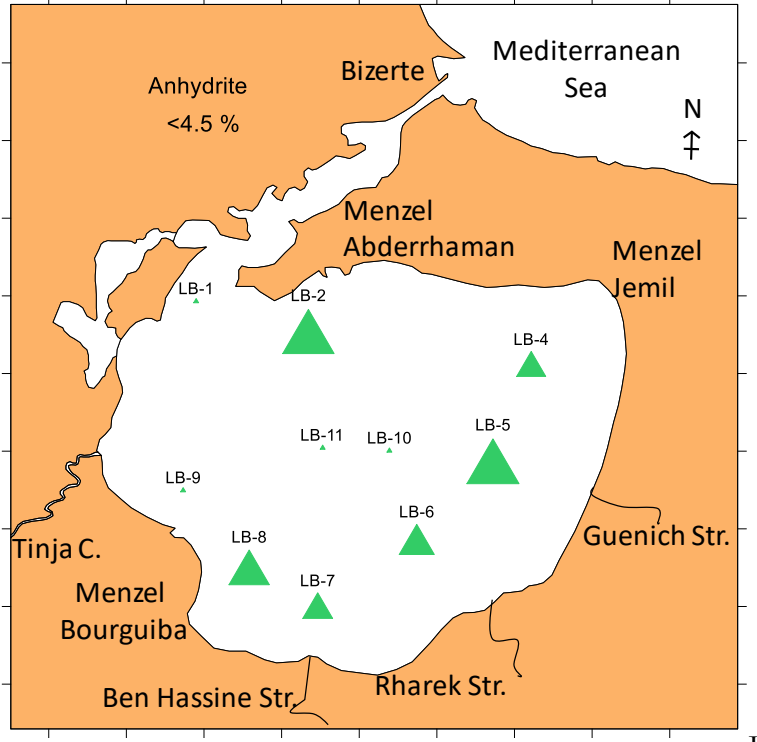

Fig. 3. (cont.) Distribution maps of the percentage (\%) of sedimentary minerals in the studied stations: G) Plagioclase; H) Siderite; I) Berthierine ferrous, J) Anhydrite. The main cities and streams are indicated. The main cities and streams are indicated. Legend C. Channel; Str. - Stream.

\subsection{Geochemical results}

Results of geochemical analyses are presented in Appendix 1. Figure 4 (A-F) includes the distribution maps of some chemical elements' concentrations (Appendix 1), such as $\mathrm{Al}(\%), \mathrm{Fe}(\%), \mathrm{Ca}(\%), \mathrm{Sr}\left(\mathrm{mg} \mathrm{kg}^{-1}\right), \mathrm{S}(\%)$ and $\mathrm{P}$ $(\%)$. Aluminum reaches highest concentrations mainly in the western region of the Bizerte Lagoon and also in LB2 station (Fig. 4A). Iron contents are high in this lagoon but decrease significantly in LB5, LB6 and LB10 stations (Fig. 4B). Calcium and $\mathrm{Sr}$ concentrations are high in the eastern region of the lagoon (Figs. 4C and 4D). Sulfur contents increase mostly in the northern and SW parts of the lagoon (Fig. 4E) and $\mathrm{P}$ concentrations rise mostly in front of the main cities.

\subsection{Statistical results}

The results of the R-mode cluster analysis (CA) are presented in Figure 5. The resulting dendrogram compares the distribution of selected textural, mineralogical, geochemical, and physicochemical data. This analysis groups the variables in three main groups. Group 1 is composed by sorting, SMGS, sand fraction, magnetic susceptibility, Eh, calcite, K-feldspar, dolomite, magnetite-maghemite, hematite, $\mathrm{Zr}, \mathrm{S}, \mathrm{Ba}, \mathrm{Mn}, \mathrm{Na}, \mathrm{Hf}, \mathrm{Nb}$, and Ta. Group 2 includes clay fraction, $\mathrm{Li}, \mathrm{Al}, \mathrm{Fe}$, anhydrite, siderite, phyllosilicates and berthierine ferrous. Group 3 encompasses silt fraction, plagioclase, anatase, quartz, pyrite, TOC, $\mathrm{Sr}, \mathrm{Ca}$ and $\mathrm{pH}$. 

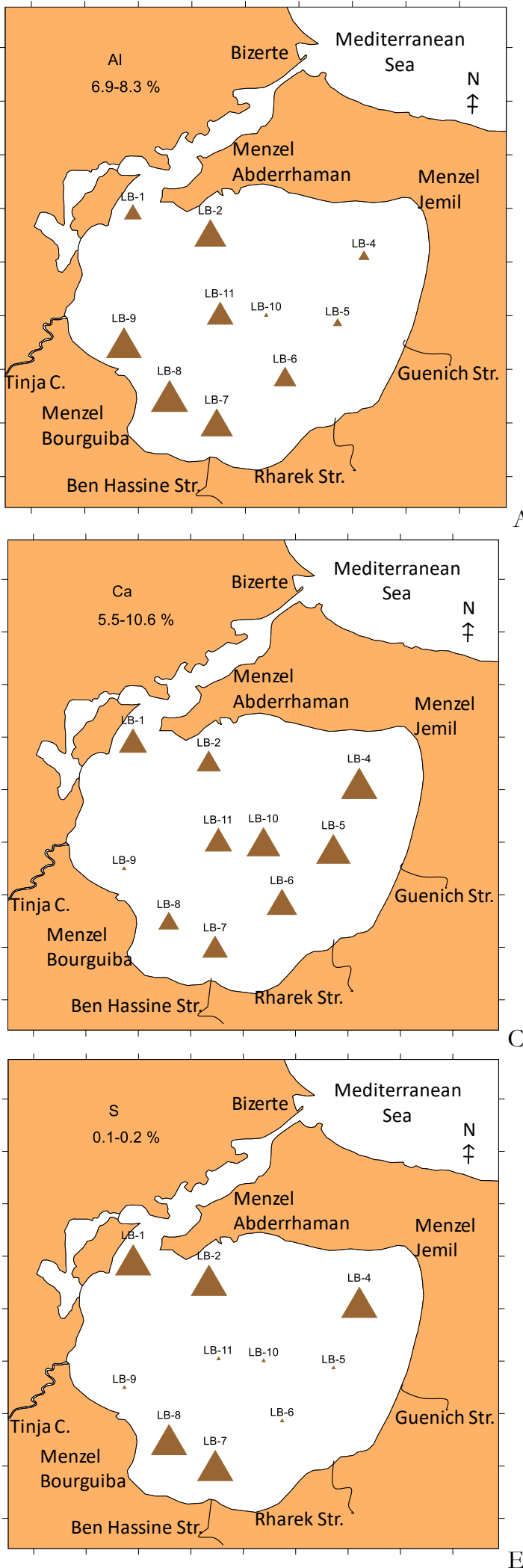
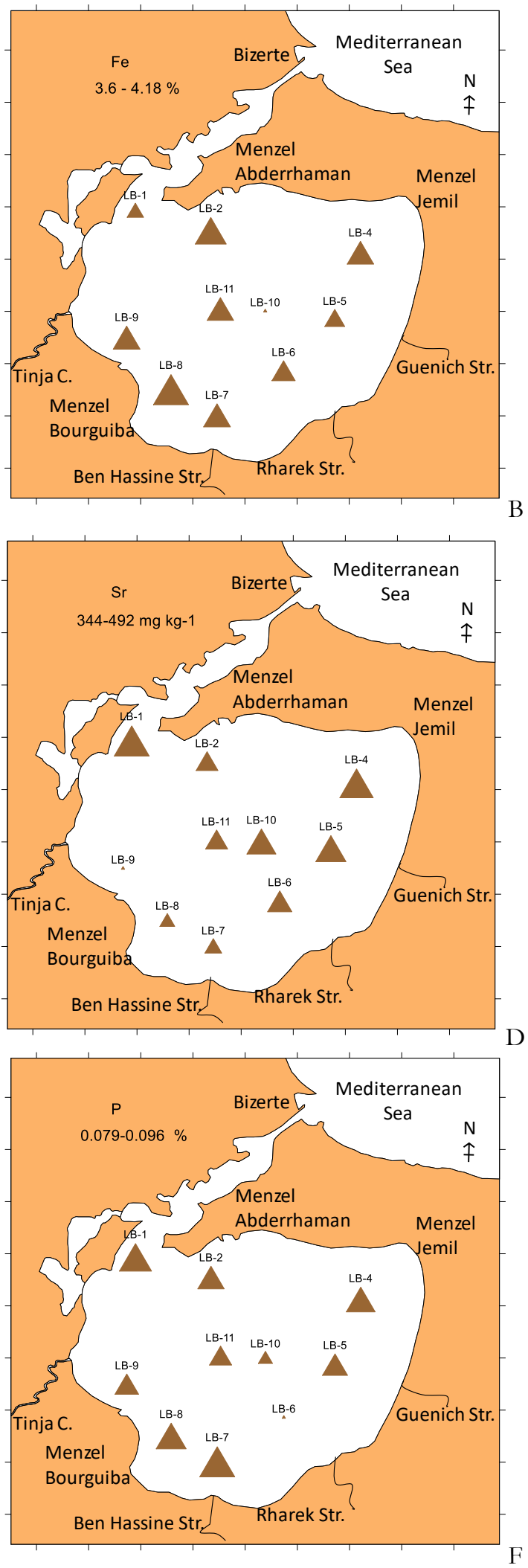

Fig. 4. Distribution maps of selected chemical elements concentrations in the sediment from the studied stations: A) Al (\%); B) Fe (\%); C) $\mathrm{Ca}(\%)$; D) Sr $\left(\mathrm{mg} \mathrm{kg}^{-1}\right)$; E) S (\%) and; F) P (\%). The main cities and streams are indicated. Legend C. - Channel; Str. - Stream. 


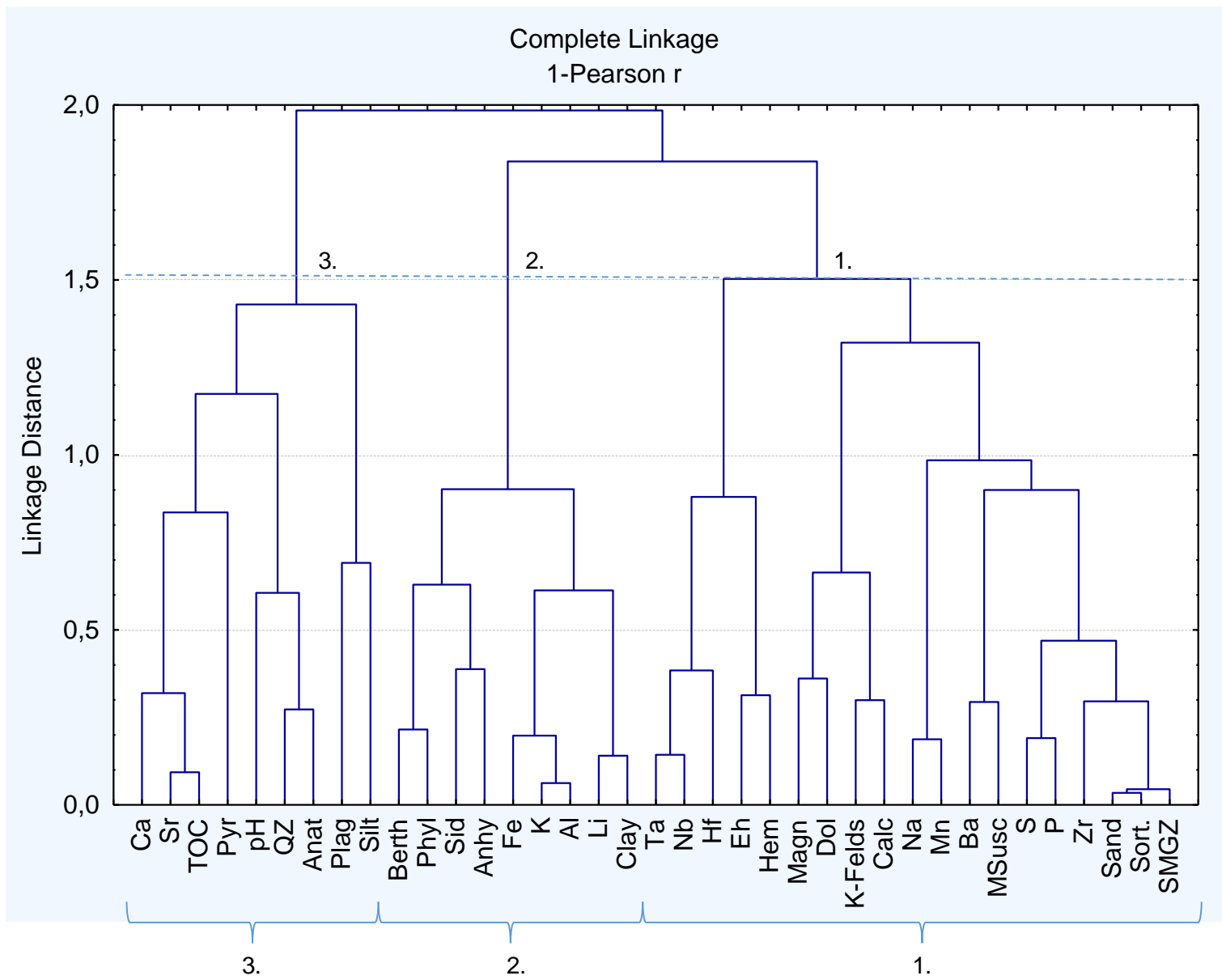

Fig. 5. Dendrogram resulting from R-mode cluster analysis comparing the distribution of textural, mineralogical, geochemical and physicochemical variables in the study area. Legend: SMGZ - Sediment Mean Grain Size; Sort - Sorting; Sand Fraction; Silt Fraction; Clay Fraction; Anat - anatase; Anhy - anhydrite; Calc - calcite; Dol - dolomite; K-Felds - K-feldspars; Phyl - phyllosilicates; Hem hematite; Magn - magnetite-maghemite; Plag - plagioclase; Pyr - pyrite; QZ - Quartz; Sid - siderite; Berth - berthierine ferrous; $\mathrm{pH}$, Eh - potential redox; MSusc - magnetic susceptibility; TOC - total organic carbon; chemical elements (Al, Ba, Ca, Fe, Hf, K, Li, Mn, $\mathrm{Na}, \mathrm{Nb}, \mathrm{P}, \mathrm{S}, \mathrm{Sr}$, Ta and Zr).

The distribution pattern of the element/ $\mathrm{Al}$ ratios was compared with TOC and selected textural, mineralogical data by R-mode CA (Fig. 6). The results of this analysis show that the distribution pattern of: $\mathrm{Hf} / \mathrm{Zr}$ (Fig. 7A) is similar to quartz distribution (Group 3); and most of the analyzed element ratios $\mathrm{Zr} / \mathrm{Al}$ (Fig. 7B), $\mathrm{Mg} / \mathrm{Al}, \mathrm{Ca} / \mathrm{Al}$ (Fig. 7C), $\mathrm{Fe} / \mathrm{Al}$ (Fig. 7D), K/Al, Nb/Al, Mn/Al, Sr/Al and $\mathrm{Hf} / \mathrm{Al}$ mainly follow TOC and pyrite distribution patterns (Group 2).

Principal Components Analysis (PCA) was applied to the variables used in the R-mode CA of Figure 6. The three first factors explain $74 \%$ of data variability $(39 \%, 23 \%$ and $12 \%$ respectively). The Factor Loadings Extraction are presented in Table 1. According to these results, the increase of: TOC and most of the elemental ratios are positively related to the first Factor Loading; whereas plenty minerals, except quartz, are positively related to the second Factor Loading; SMGS and sorting are positively related to the third Factor Loading.
The values of the three first factors scores of PCA are mapped (Fig. 8). These maps discriminate different zones in the lagoon.

\section{Discussion}

\subsection{General characteristics of sediments}

In the studied stations of the Bizerte Lagoon, the sediments are commonly fine grained. The sediments with coarser grain size (Fig. 2A) and relatively high values of sorting (Fig. 2B), skewness and kurtosis are encountered in the northern region of the lagoon near the channel of communication with the Mediterranean Sea and in front of the mouth of the Ben Hassine stream. These data well agree with those of Kamens et al. (1984), Soussi et al. (1983), Ouakad (1993, 2007) and Romdhane and Belkhouja (2004). According to these authors, mud facies are found in the entire central area, in the western and south-western sides of 
the lagoon. These areas function as traps for the fine sediment coming from river inputs. When moving toward the northern, eastern and southeastern coastal areas of the lagoon, the fine fraction tends to decrease and is gradually mixed with coarse fractions. As observed in this study, the coarser sediment fraction in those zones is mainly composed by fragments of mollusk shells.

The sediments' granulometry in the lagoon is influenced by the hydrodynamics. As observed by Béjaoui and Harzallah (2005) and Fertouna-Bellakhal et al. (2014), tidal currents are stronger on the northern margin and near the entrance channel and decrease considerably within the lagoon.

The hydrodynamics of the lagoon is mainly driven by the wind force, which induce seasonal changes in circulation, and by tidal currents but is in general weak in its inner areas (Kallel, 1989; Sakka Hlaili et al., 2008). Thus the increase of the granulometry near the Ben Hassine stream mouth may reflect a greater competence of transport of this stream in relation to the other streams that flow into the lagoon.

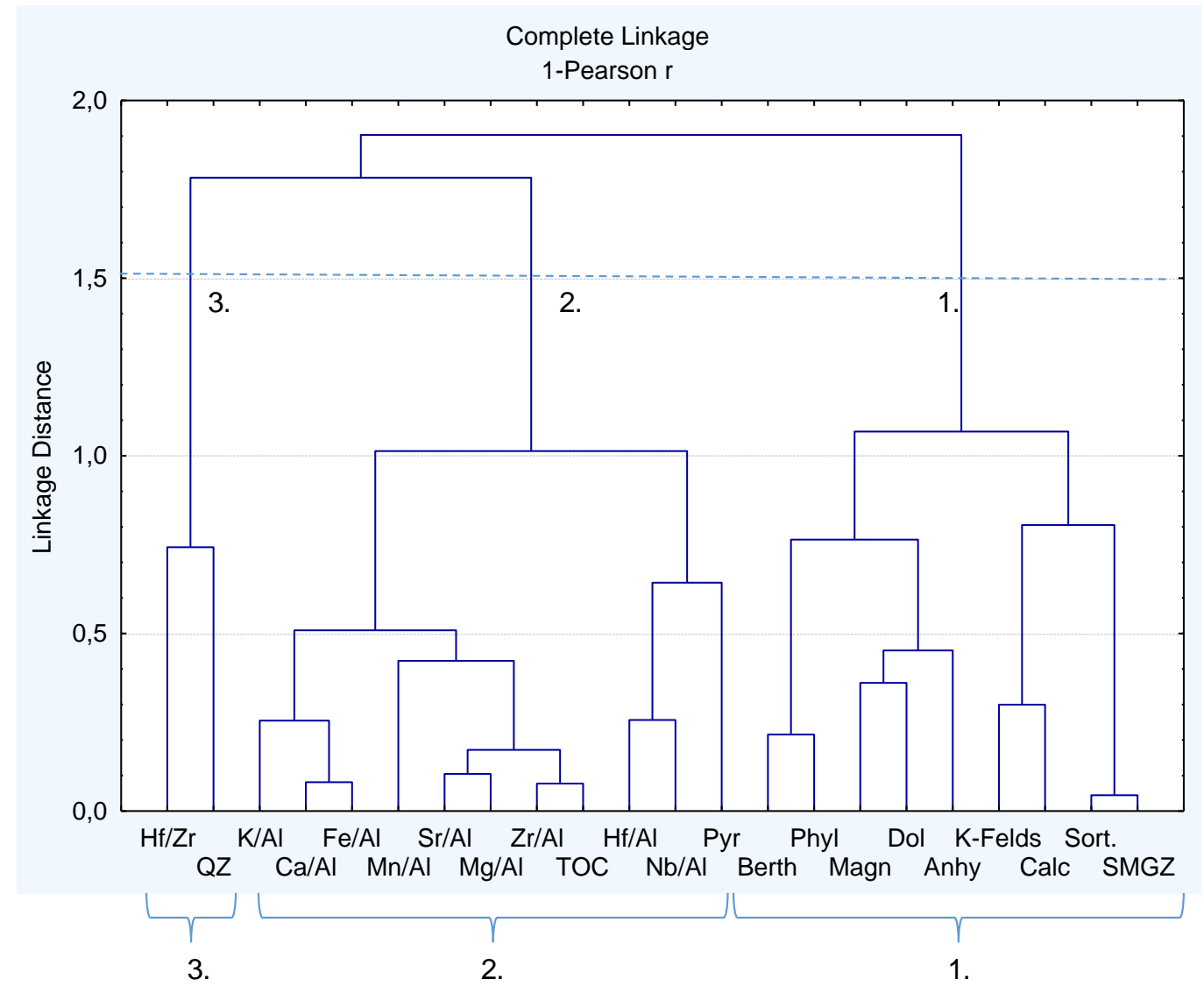

Fig. 6. R-mode cluster analysis comparing the distribution of selected textural, mineralogical and geochemical variables analyzed in the study area. Legend: SMGZ - Sediment Mean Grain Size; Sort - Sorting; Anhy - anhydrite; Calc - calcite; Dol - dolomite; K-Felds - Kfeldspars; Phyl - phyllosilicates; Magn - magnetite-maghemite; Pyr - pyrite; QZ - Quartz; Berth - berthierine ferrous; TOC - total organic carbon, and element/Al ratios (Mg/Al, Fe/Al, Ca/Al, K/Al, Zr/Al, Nb/Al, Mn/Al, Sr/Al, Hf/Al and Hf/Zr).

The high TOC content (average 4.2\%; Appendix 1) is also generally associated with high biological productivity and with allochthonous contributions of organic materials and with the deposition of fine grained sediments (silt fraction; Group 3 of Fig. 5) under weak bottom currents.

Several works on productivity have been carried out in the Bizerte Lagoon such as Martins et al. (2015a, 2016), Zaaboub et al. (2015), among others that have suggested that the natural biological productivity within the lagoon is particularly high (e.g. Hamdi et al., 2002; Sakka Hlaili et al., 2006, 2007, 2008). The accumulation of high organic matter contents (indicated by TOC concentrations) leads to the establishment of anoxia in superficial layers of the sediment. The sediment is black a few millimeters below the surface as observed during the sampling event. The organic matter in the sediment constitutes food for benthic organisms that are generally aerobic (Martins et al., 2015a, 2016).

When nutrients are abundant, a bloom of living organisms typically occurs at various links in the food chain. The increase in living organisms leads to an excessive consumption of oxygen and to its scarcity both in the water column and the sediment (Martins et al., 2015a, 2016). The 
negative values of Eh indicate the lack of oxygen in the surface sediments.

The sediments, in the studied stations, are essentially constituted by phyllosilicates (mean 42\%, Fig. 3A). The phyllosilicates contents, including berthierine ferrous (hydrous aluminum silicate of iron), are associated with clay fraction (Group 2 of Fig. 5) since they are deposited mostly in areas where the currents activity is weak (Martins et al., 2015a).

Berthierine ferrous should also be an autochthonous mineral formed within the lagoon. This mineral is common

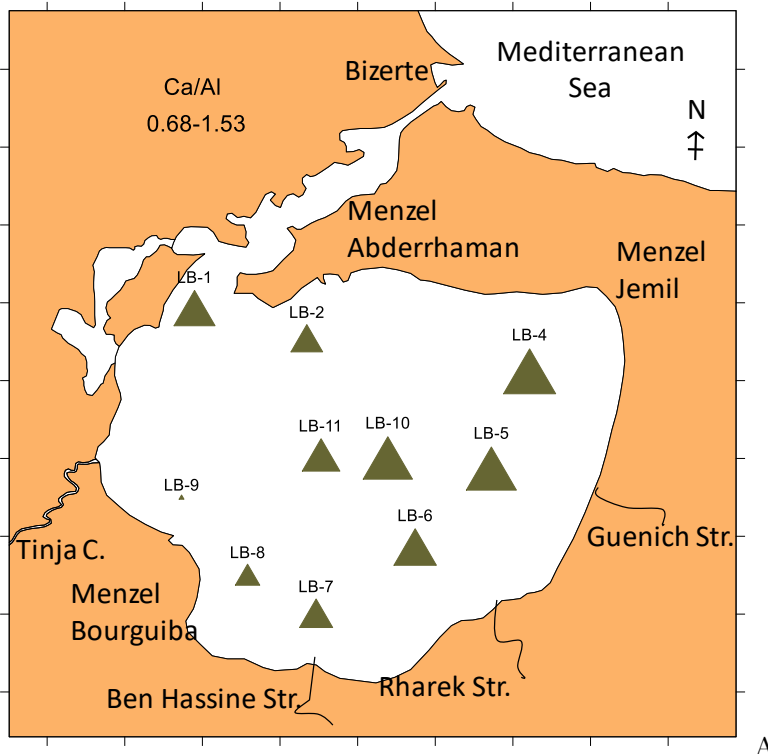

A

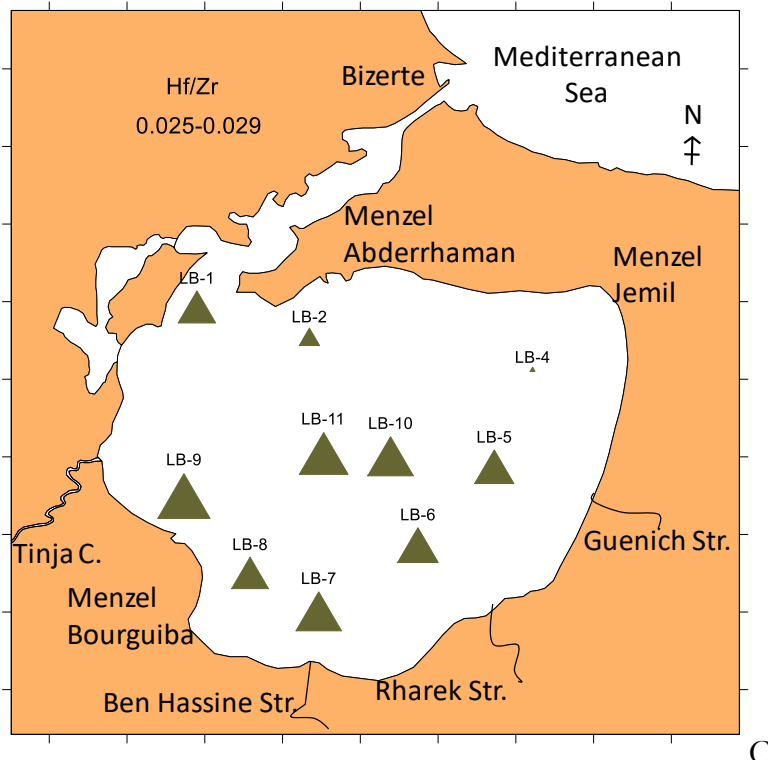

near the margins of the lagoon (Fig. 3I). Its formation process is still poorly understood, however, this mineral may eventually be formed in low oxic environments (Bhattacharyya, 1983).

The phyllosilicates content is also reflected (Group 2 of Fig. 5) in the high $\mathrm{Al}$ concentrations (mean 7.5\%; Fig. 4A) of the Bizerte Lagoon sediments as well as with Fe (Fig. 4B), $\mathrm{Li}$ and $\mathrm{K}$ given the chemical composition of these minerals (Dyar et al., 2008; Lauf, 2008). They have also a similar pattern of distribution of other minerals such as anhydrite and siderite (Group 2 of Fig. 5).
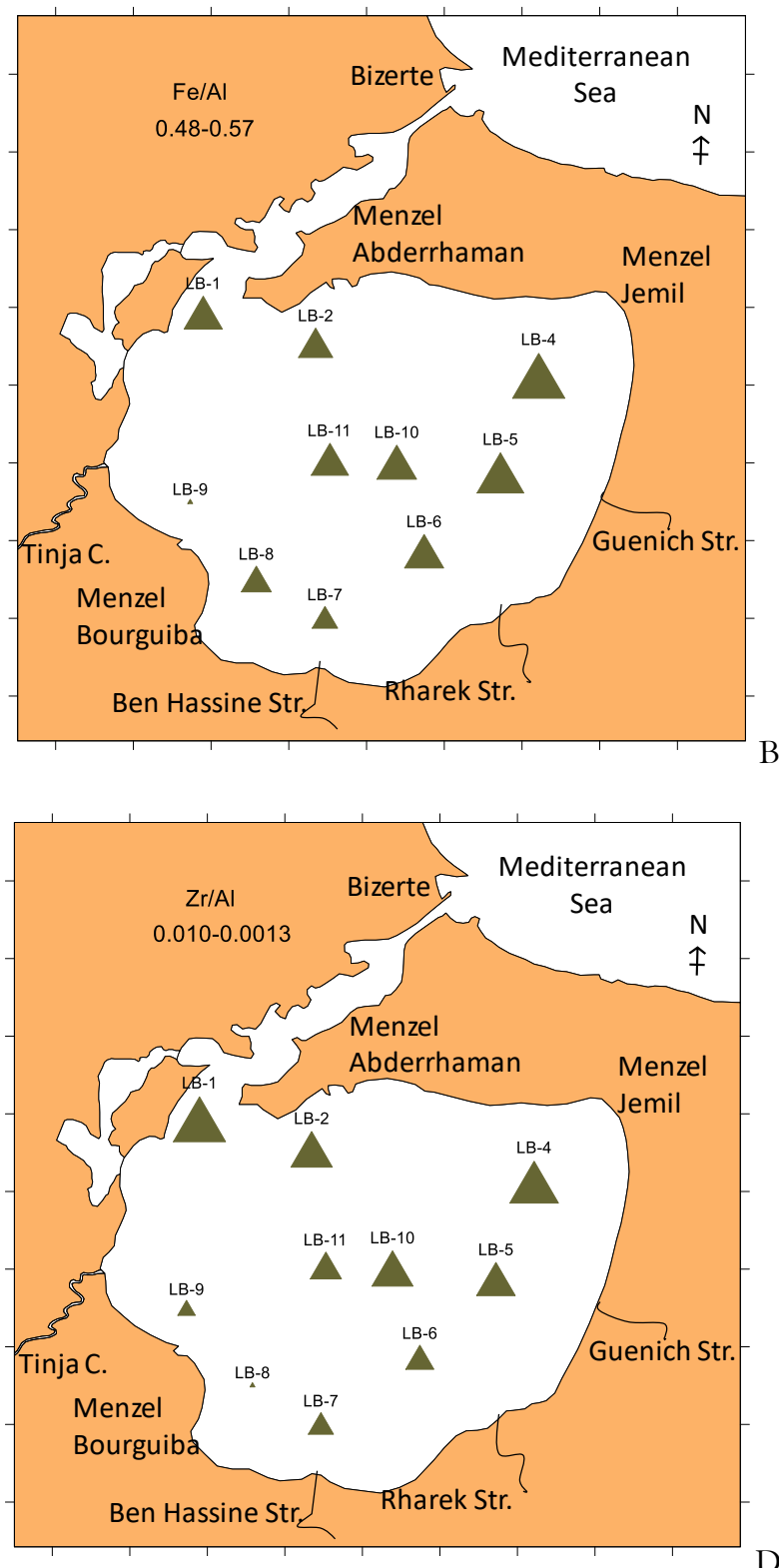

Fig. 7. Maps of distribution of: A. Ca/Al; B. Fe/Al; C. Hf/Zr; D. Zr/Al. Legend: C. - Channel; Str. - Stream. 
Tab. 1. Factor Loadings Extraction by Principal Components Analysis. Marked loadings are $p>0.50$. Legend: SMGZ - Sediment Mean Grain Size; Sort - Sorting; Anhy - anhydrite; Calc - calcite; Dol - dolomite; K-Felds - K-feldspars; Phyl - phyllosilicates; Magn - magnetite/ magnesite; Pyr - pyrite; QZ - Quartz; Berth berthierine ferrous; TOC - total organic carbon, and element/Al ratios $(\mathrm{Mg} / \mathrm{Al}, \mathrm{Fe} / \mathrm{Al}, \mathrm{Ca} / \mathrm{Al}, \mathrm{K} / \mathrm{Al}, \mathrm{Zr} / \mathrm{Al}, \mathrm{Nb} / \mathrm{Al}, \mathrm{Mn} / \mathrm{Al}, \mathrm{Sr} / \mathrm{Al}$, $\mathrm{Hf} / \mathrm{Al}$ and $\mathrm{Hf} / \mathrm{Zr}$ ).

\begin{tabular}{|c|c|c|c|}
\hline Variables & $\begin{array}{c}\text { Factor } \\
1\end{array}$ & $\begin{array}{c}\text { Factor } \\
2\end{array}$ & $\begin{array}{c}\text { Factor } \\
3\end{array}$ \\
\hline SMGZ & 0.14 & 0.43 & 0.85 \\
\hline Sort. & -0.03 & 0.53 & 0.79 \\
\hline Anhy & -0.04 & 0.69 & -0.43 \\
\hline Calc & 0.58 & 0.55 & 0.08 \\
\hline Dol & 0.02 & 0.76 & 0.10 \\
\hline K-Felds & 0.20 & 0.76 & 0.03 \\
\hline Phyl & -0.44 & 0.59 & -0.23 \\
\hline Magn & 0.11 & 0.81 & 0.25 \\
\hline Pyr & 0.40 & -0.03 & 0.08 \\
\hline QZ & 0.21 & -0.68 & 0.20 \\
\hline Berth & -0.56 & 0.72 & -0.33 \\
\hline TOC & 0.91 & 0.10 & 0.18 \\
\hline $\mathrm{Mg} / \mathrm{Al}$ & 0.95 & -0.05 & -0.19 \\
\hline $\mathrm{Fe} / \mathrm{Al}$ & 0.85 & 0.09 & -0.42 \\
\hline $\mathrm{Ca} / \mathrm{Al}$ & 0.87 & 0.00 & -0.27 \\
\hline $\mathrm{K} / \mathrm{Al}$ & 0.78 & -0.08 & -0.40 \\
\hline $\mathrm{Zr} / \mathrm{Al}$ & 0.93 & 0.10 & 0.25 \\
\hline $\mathrm{Nb} / \mathrm{Al}$ & 0.65 & -0.15 & 0.16 \\
\hline $\mathrm{Mn} / \mathrm{Al}$ & 0.72 & 0.22 & -0.14 \\
\hline $\mathrm{Sr} / \mathrm{Al}$ & 0.96 & -0.06 & -0.09 \\
\hline $\mathrm{Hf} / \mathrm{Al}$ & 0.76 & -0.37 & 0.46 \\
\hline $\mathrm{Hf} / \mathrm{Zr}$ & -0.52 & -0.67 & 0.21 \\
\hline Expl.Var. & 0.39 & 0.23 & 0.12 \\
\hline
\end{tabular}

Anhydrite, an anhydrous calcium sulfate $\left(\mathrm{CaSO}_{4}\right)$ mineral, is frequently found in evaporitic deposits and is common in salt basins. Anhydrite is commonly associated with calcite, halite, and sulfides such as pyrite (Deer et al., 1992). It can be formed from an aqueous solution where calcium sulfate is deposited as crystals of gypsum, but when the solution contains an excess of sodium or potassium chloride, anhydrite is deposited if the temperature is above $40^{\circ} \mathrm{C}$ (Deer et al., 1992). Thus this mineral might also be produced during the desiccation of sediments and corresponds to an artificially prepared species of mineral formed during the sediments preparation for mineralogical analysis by XRD. However, this mineral was not identified in the central area of the lagoon and near the connection with the Mediterranean Sea and the Tinja Channel, which may indicate that it makes part of the minerals present in the lagoon sediments and may be formed as a consequence of evaporate phenomenon at the margins before being introduced in the lagoon by erosion of the sediments by waves and curling. On the other hand, the enhanced concentration of sodium chloride during the year resulting from scrubbing the Triassic sediments in the catchment area and input from the Tinja Channel and Rharek Streams (Garali et al., 2011). According to Zaaboub et al. (2016), in front of these connected water flows metal availability is increased under the effect of dissolved salts, an enhanced sodium chloride concentration (Riba et al., 2003).

Although siderite content is limited, this mineral is also associated with clay fraction (Group 2 of Fig. 5). Its distribution map (Fig. $3 \mathrm{H}$ ) reveals that this mineral is relatively more abundant on the lagoon margins, where there are industrial activities (iron works and foundry companies). The siderite is practically absent in the center of the lagoon where there are relatively high levels of pyrite, particularly in the LB11 station. Siderite is frequently formed at low temperatures in the anoxic zone by bacterial methanogenesis (Curtis et al., 1986). Because siderite is frequently one of the earliest minerals to precipitate in sediments, there has been considerable interest in using siderite geochemistry as an indicator of depositional environment (Mozley and Wersin, 1992).

The TOC content is also (Group 3, Fig. 5) related to Ca (Fig. 4C) and Sr (Fig. 4D). This relationship allows us to deduce that part of the $\mathrm{Ca}$ and $\mathrm{Sr}$ values are related to natural and man-induced biological productivity within the lagoon, principally to organisms with carbonate shells (such as mollusks). This ecosystem has been used to mollusks farming (Khessiba et al., 2001). These harvests, located mainly in the eastern sector of the lagoon, are additional sources of organic matter for the sediment, and of carbonates, which are reflected in the distribution maps of TOC (Fig. 2D), Ca (Fig. 4C) and Sr (Fig. 4D). The TOC content have also similar patterns of distribution (Group 2 of Fig. 5) to several minerals such as quartz (Fig. 3B), pyrite (Fig. 3C), anatase (Fig. 3E), plagioclase (Fig. 3G) and as well as to $\mathrm{pH}$. However, quartz, anatase and plagioclase increase mostly near the connection with the Mediterranean Sea. The two first minerals increased significantly in the central area of the lagoon, whereas plagioclase is more frequent in front of the Rharek and Guenich streams. The distribution pattern of these minerals indicates: i) relatively energetic hydrodynamic conditions (marked by coarse sediments) and efficiency of transport of sediments from the Mediterranean Sea to the lagoon in the outer sector of the lagoon; ii) the lagoon central area is a depocenter of fine grained terrigenous materials deposited from wind contributions and favorable currents activity or due to the morphology of this region; and iii) the streams introduce different lithological contributions in the lagoon.

The presence of pyrite $(\mathrm{FeS})$ in all studied samples is also associated with the occurrence of high organic matter content and anoxia below the water-sediment interface. 
Pyrite is formed in neutral and alkaline solutions, such as those found in the sediments of the Bizerte Lagoon (Group 3 of Fig. 5), and is preserved in anoxic layers with reduced redox potential values (Froelich et al., 1988).

The relatively coarse sediment fractions (indicated by SMGS and sand fraction in Group 1 of Fig. 5) are related to sorting and moderately high values of Eh (however quite negative). The increase of particles size probably allows a better renovation of pore-water and sedimentary oxygenation. The somewhat coarse sediment fractions are also associated with some lithogenic components including calcite, dolomite, magnetite-maghemite, K-feldspar, hematite, and is associated with relatively high values of magnetic susceptibility and several chemical elements such as $\mathrm{P}, \mathrm{Zr}, \mathrm{Ta}, \mathrm{Nb}$ and $\mathrm{Hf}$ (Group 1 of Fig. 5).

The abundance of carbonate bioclasts (mollusk shells, ostracod valves and foraminiferal tests) are reflected in calcite contents (average 26\%, Fig. 3D). Carbonates should be supplied to the lagoon from the Cretaceous to Eocene calcareous rock (Roger, 1955) in addition to the biogenic component of the sediment that are the main constituents of the sand fraction, in most of the studied samples located in the northern and eastern zones of the lagoon, as shown by a qualitative analysis at the light microscope.

Dolomite is a calcium magnesium carbonate common in sedimentary rocks. Modern dolomite formation has been found to occur in natural environments rich in organic matter and microbial cell surfaces (Roberts et al., 1980). It is also formed under anaerobic conditions with the help of sulfate-reducing bacteria supersaturated saline lagoons along the Rio de Janeiro coast of Brazil, such as Lagoa Vermelha (Vasconcelos et al., 1995).

Iron oxides such as magnetite $\left(\mathrm{Fe}_{3} \mathrm{O}_{4}\right)$ and maghemite $(\gamma$ $\left.\mathrm{Fe}_{2} \mathrm{O}_{3}\right)$ are ubiquitous in nature and have magnetic properties that may explain its link with relatively high magnetic susceptibility values. Maghemite can be formed by weathering or oxidation of magnetite or titanomagnetite (Anthony et al., 1997). K-feldspar is also associated with coarse sediment fraction (variables of Group 1 of Fig. 5). This mineral should be rapidly degraded in fine grained fractions and is probably transformed into kaolinite which is an abundant clay mineral in the Bizerte Lagoon (Martins et al., 2015a).

The highest concentrations of $\mathrm{P}$ (Fig. 4F) are found in very densely populated marginal areas of the lagoon, such as in front of Menzel Abderahman, Menzel Jemil and Menzel Bourguiba cities, and may indicate its release into the lagoon by domestic, municipal and industrial effluents without previous treatment. Although there is a treatment plant in Menzel Bourguiba (operating since January 1998), there are relatively high values of $\mathrm{P}$ near this city. These values may also be associated with the Ben Hassine stream contribution.

As above mentioned, high $\mathrm{P}$ concentrations trigger biological productivity, which is also reflected in sedimentary Ca contents. Much of the Ca should be supplied by mollusks that live naturally in the lagoon or in harvests (mussels and oysters). They release excretions into the sediment, which results into additional organic matter accumulation. The decomposition of organic materials generates anoxia and sulphides production, such as pyrite. Sulphides production contributes for the retention of $\mathrm{S}$ in conjunction with other chemical elements (Liu et al., 2016 and references herein) in areas of active sedimentary biogeochemical activity (Martins et al., 2015b). The changes reflect enhancement of microbial sulfate reduction in organic matter rich sediments and the progressive formation of hypoxic-anoxic conditions (Hargrave et al., 2008).

Lithogenic elements such as Zr, Ta, Nb and Hf (Group 1 of Fig. 5) may be related to granites. Tantalum and niobium mineralization is mainly associated with albite rich zones in granites (Pollard, 1989). Hafnium is also a common chemical element in granites and diorites as well as $\mathrm{Zr}$ (Pollard, 1989). The values of $\mathrm{Hf} / \mathrm{Zr}$ ratio, used to discriminate different types of granites (ranging from 0.025-0.029, mean 0.027), are higher than several types of granites including granite pegmatites (Currie, 1968). The Hf/Zr values are related to quartz enrichment (Group 2 of Fig. 6). The lowest values of $\mathrm{Hf} / \mathrm{Zr}$ are observed in the northern and eastern zones of the Bizerte Lagoon and the highest in the southern and central areas of the lagoon (Fig. 7). The increase of the other element/Al ratios (such as $\mathrm{K} / \mathrm{Al}, \mathrm{Fe} / \mathrm{Al}, \mathrm{Ca} / \mathrm{Al}, \mathrm{Zr} / \mathrm{Al}$, $\mathrm{Hf} / \mathrm{Al}, \mathrm{Nb} / \mathrm{Al}, \mathrm{Sr} / \mathrm{Al}$ and $\mathrm{Mg} / \mathrm{Al}$ ) seems to be related to areas with highest TOC and pyrite content (Group 2 of Fig. 6 ), which indicates that low hydrodynamic conditions and/or processes of early diagenesis of organic matter may also influence the retention of lithogenic elements.

\subsection{Zonography of the Bizerte Lagoon using textural, geochemical and mineralogical fingerprints of the sediments}

According to Kamens et al. (1984; 1989), the main sediment inputs to the lagoon are for instance: (i) a noncalcareous mud and sand transported by Tinja Channel from Ichkeul Lake; (ii) limestone and solid material due to soil erosion of adjacent cropland brought by rivers; (iii) silt and clay in atmospheric compounds; (iv) inputs from the Mediterranean Sea and; (v) carbonate from marine organisms.

Results of this work also indicate that the accumulation of fine grained sediments and organic matter in the lagoon contributes to change the elemental and mineralogical composition of the sediments of the Bizerte Lagoon. These alterations may include the production of minerals such as pyrite, berthierine ferrous, dolomite and siderite and the retention of chemical elements in reduced layers of the sediment (as indicated by Group 2 of Fig. 6 CA).

The three first factor loadings (of PCA, Fig. 8) allow to discriminate different areas in the Bizerte Lagoon. The factor loading 1 (Fig. 8A) discriminates the northern and eastern areas of the lagoon, where the contribution of TOC (Fig. 2D) and the carbonated biogenic component reach 
highest values (Fig. 7A, Fig. 3D) as well as $\mathrm{Fe}$ due to industrial activities (Fig. 7B); in opposition to this region, the western part of the lagoon is characterized by an important lithogenic contribution probably provided by the Ben Hassine Stream, Tinja Channel and terrigenous transported particles by wind. The lithological differences between the northern/eastern and western zones of the lagoon are also expressed by the $\mathrm{Hf} / \mathrm{Zr}$ (Fig. 7C) and $\mathrm{Zr} / \mathrm{Al}$ (Fig. 7D) ratios. Whereas the values of $\mathrm{Hf} / \mathrm{Zr}$ ratio increase mostly in the western, south and central areas of the lagoon, the $\mathrm{Zr} / \mathrm{Al}$ ratio presents an opposite trend. This opposite trend may identify different rock sources of the sediments and/or different processes of transportation and deposition of sediments.

The factor loading 2 (Fig. 8B) discriminates the marginal area of the lagoon, where increases the presence of minerals such as berthierine ferrous, anhydrite, dolomite and siderite in relation to the central zone of the lagoon. This area is under waters that return to the ocean after several days inside the lagoon (Harzallah, 2003; Béjaoui, 2009). The velocity of the currents is calm, which allows the deposition of fine detrital material. However, minerals that are more resistant to weathering (such as quartz and anatase) are deposited in here. More easily altered minerals such as plagioclase and Kfeldspar substantially reduce their presence in sediment composition.

The works of Soussi (1981) and Kamens et al. (1984) show that sediment distribution in the Bizerte Lagoon depends on inputs and also on its bottom morphology. The long residence time of water within the lagoon (Harzallah, 2003) contributes to their impoverishment in oxygen. The oxygen demand in water overlying the sediment makes the environment less favorable to benthic life, what is expressed into the decrease in TOC values and relatively low calcite contents (associated essentially with mollusk, ostracod and foraminiferal carbonate bioclasts) in the central area of the lagoon.

The factor loading 3 (Fig. 8C) distinguishes the most confined areas where currents activity is weak and allows the deposition of very fine grained sediments, from that where the hydrodynamism is relatively stronger.

\section{Conclusion}

The Bizerte Lagoon is a shallow coastal system, connected with the Mediterranean Sea through a channel, where the coastal currents are weak allowing the accumulation of fine sediments and organic matter. The organic materials in the lagoon should be related to high biological productivity, probably stimulated by the excessive input of nutrients from anthropic activity. High deposition of organic matter results in the presence of a reducing condition in bottom sediment environment in many places. Mollusks culture also influences the high levels of TOC in the sediment and its own carbonate composition.
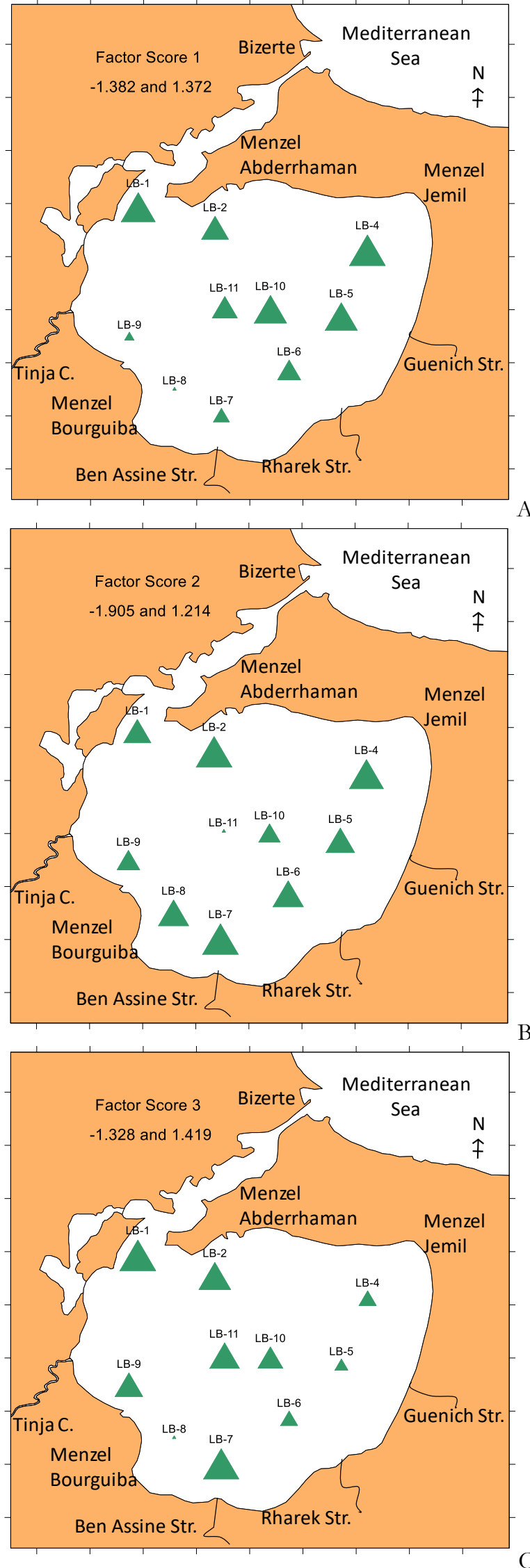

Fig. 8. Distribution maps of the three first factors scores of Principal Components Analysis based on the same variables used in the cluster analyses of Figure 6. 
The biological productivity also influences the mineralogical composition of the sediment, expressed by the presence of pyrite, berthierine ferrous and dolomite, which can be formed in reducing environments, and may constitute an autochthonous contribution of minerals for the sediment.

The circulation of the currents and the time of the water permanence inside the lagoon influence the mineralogical and geochemical characteristics of the sediments. The industrial activity is also an important factor, since it results in the accumulation of high concentrations of some metals, such as Fe.

However, differences in the lithogenic composition of the sediments supplied to the western, southern and central part of the lagoon probably provided by the Ben Hassine and Rharek streams, Tinja Channel and wind force are highlighted through geochemical fingerprints. These fingerprints indicate that these regions receive contributions from different rocks composition or different processes of transport and deposition of sediments and different processes of production of autochthonous materials.

\section{Acknowledgments}

This work was partially supported by funds from Research Unit UID/GEO/04035/2013 (FCT, Portugal) and by the bilateral cooperation project Portugal / Tunisia 48/TP/09.

Appendix 1 is attached as supplementary material 1 (SM1) in http://www.e-

publicacoes.uerj.br/index.php/jse/article/view/26881

\section{References}

Adamovič, J., 2009. Earth System: history and natural variability. Vol. I - Sedimentary Rocks. Encyclopedia of Life Support Systems (EOLSS).

Afli, A., Ayari, R., Zaabi, S., 2008. Ecological quality of some Tunisian coast and lagoon locations, by using benthic community parameters and biotic indices. Estuarine, Coastal and Shelf Science 80, 269-280. doi.org/10.1016/j.ecss.2008.08.010

Anthony, J.W., Bideaux, R.A., Bladh, K.W., Nichols, M.C., eds. (1997). Maghemite. Handbook of Mineralogy. III (Halides, Hydroxides, Oxides). Chantilly, VA, US: Mineralogical Society of America. ISBN 0962209732.

Barhoumi, B., Elbarhoumi, A., Clérandeau, C., Al-Rawabdeh, A.M., Atyaoui, A., Touil, S., Driss, M.R., Cachot, J., 2016. Using an Integrated Approach to Assess the Sediment Quality of an Mediterranean Lagoon, the Bizerte Lagoon (Tunisia). Ecotoxicology 25 (6), 1082-1104. doi:10.1007/s10646-0161664-4

Béjaoui, B., Solidoro, C., Harzallah, A., Chevalier, C., Chapelle, A., Zaaboub, N., Aleya, L., 2016. 3D modeling of phytoplankton seasonal variation and nutrient budget in a southern Mediterranean Lagoon. Marine Pollution Bulletin. doi.org/10.1016/j.marpolbul.2016.11.001

Béjaoui, B., 2009. Développement d'un Modèle Tridimensionnel Couplé Dynamique-Ecologie: Application à la Lagune de
Bizerte. Rapport de thèse de spécialité en génie hydraulique. ENIT, Département d'hydraulique. 210 p.

Béjaoui, B, Harzallah, A., Moussa, M., Chapelle Annie, Solidoro, C., 2008. Analysis of hydrobiological pattern in the Bizerte lagoon (Tunisia). Estuarine, Coastal and Shelf Science, 80(1), 121-129. http://doi.org/10.1016

Béjaoui, B., Harzallah, A., 2005. Modèle hydrodynamique de la lagune de Bizerte avec forçage saisonnier. Atelier de Modélisation des Écosystèmes Marins, organisé par l'INSTM, Tunis, 27-28 Septembre 2005.

Ben Ismail, S., Sammari, C., Gasparini, G.P., Béranger, K., Brahim, M., Aleya, L., 2012. Water masses exchanged through the channel of Sicily: evidence for the presence of new water masses on the Tunisian side of the channel. Deep-Sea Research Science $63,65-81$.

Bhattacharyya, D.P., 1983. Origin of berthierine in ironstones. Clays and Clay Minerals 31 (3), 173-182

Boggs, S. Jr., 2009. Petrology of Sedimentary Rocks. Cambridge University Press, England. Hardback, Second Edition, 600 p.

Boggs, S. Jr., 2006. Principles of sedimentology and stratigraphy. Upper Saddle River, New Jersey, Pearson Prentice Hall, 4th ed.

Burollet, P.F., 1951. Etude Géologique des Bassins Mio-Pliocenes du Nord-Est de la Tunisie. Annales des Mines et de la Géologie 7, 5-86.

Button, A., 1982. Sedimentary iron deposits, evaporates and phosphorites: State of the art report. In H.D. Holland and M. Schidlowski, Eds., Mineral Deposits and the Evolution of the Biosphere, Springer-verlag, New York, p. 259-273.

Crampon, N., 1971. Etude Géologique de la Bordure des Mogods du 'Pays de Bizerte' et du Nord de Hedil (Tunisie Septentrionale). Docteur ès Sciences, Nancy I.

Currie, K.L., 1968. Variations in the hafnium/zirconium ratio of high grade metamorphic rocks from Southeastern Ontario, Canada. Earth and Planetary Science Letters 4 (4), 299-304. doi:10.1016/0012-821X(68)90091-5

Curtis, C.D., Coleman, M.L., Love, L.G., 1986. Pore water evolution during sediment burial from isotopic and mineral chemistry of calcite, dolomite and siderite concretions. Geochimica et Cosmochimica Acta 50, 2321-2334. doi:10.1016/0016-7037(86)90085-2

Dean, W. E., Fouch, T.D., 1983. Lacustrine environment. In Scholle, P.A., Bebout, D.G. and Moore, C.H., Carbonate Depositional Environments, AAPG Memoir 33, pp. 97-130.

Dean, W.E., 1982. Theoretical versus observed successions from evaporation of seawater, in W. E. Dean and B. C. Schreiber (eds.), Marine Evaporites: SEPM Short Course Notes 4, pp. 74 85.

Dean, W.E., Davies, G.R., Anderson, R.Y., 1975. Sedimentological significance of nodular and laminated anhydrite. Geology 3, 367372.

Deer, W.A., Howie, R.A., Zussman, J., 1992. An Introduction to the Rock Forming Minerals (2nd ed.). England: Pearson Education. p. 614. ISBN0-582-30094-0.

Dyar, M.D., Gunter, M. E., Tasa, D., 2008. Mineralogy and Optical Mineralogy. Mineralogical Society of America.

Essid, N., Aissa, P., 2002. Etude quantitative des nématodes libres des secteurs Nord et Est de la lagune de Bizerte (Tunisie). 
Institut National des Sciences et Technologies de la Mer I.N.S.T.M., Salammbô, Tunis 29, 53-63.

Fertouna-Bellakhal, M., Dhib, A., Béjaoui, B., Turki, S., Aleya, L., 2014. Driving factors behind the distribution of dinocyst composition and abundance in surface sediments in a western Mediterranean coastal lagoon: report from a high resolution mapping study. Marine Pollution Bulletin 84, 347-362. doi.org/10.1016/j.marpolbul.2014.04.041

Froelich, P.N., Arthur, M.A., Burnett, W.C., Deakin, M., Hensley, V., Jahnke, R., Kaul, L., Kim, K.-H., Roe, K., Soutar, A., Vathakanon, C., 1988. Early diagenesis of organic matter in Peru continental margin sediments: Phosphorite precipitation. Marine Geology, 80, 309-343. doi: 10.1016/0025-3227(88)90095-3

Garali, A.B., Ouakad, M., Gueddari, M., 2013. Episodic sedimentation of heavy metals and iron in Bizerte Lagoon, Northern Tunisia. International Journal of Geosciences 4, 24-35 doi.org/10.4236/ijg.2013.41003

Garali, A.B., Ouakad, M., Gueddari, M., 2011. The Bizerte Lagoon is classified in the category of medium salinity environments Geochemistry and ionic interaction in the Bizerte Lagoon waters (Northern Tunisia). Journal of Oceanography and Marine Science 2(1), 1-9.

Hamdi, H., Ghribi, R., Daly-Yahia, M.N., 2002. Fluctuations printanières et estivales des communautés de copépodes pélagiques dans la lagune de Bizerte. Revue de la F.S.B - Faculté des Sciences de Bizerte 1, 200-207.

Hargrave, B.T., Holmer, M., Newcombe, C.P., 2008. Towards a classification of organic enrichment in marine sediments based on biogeochemical indicators. Marine Pollution Bulletin 56(5), 810-24. doi: 10.1016/j.marpolbul.2008.02.006.

Harzallah, A., 2003. Transport de polluants dans la lagune de Bizerte simulé par um modèle de circulation de l'eau. Institut National des Sciences et Technologies de la Mer I.N.S.T.M., Salammbô, Tunis 30, 121-133.

INSTM, 2002. Etat actuel et évolution de l'exploitation halieutique et aquacole des lagunes-Cas de la lagune de Bizerte. Rapport. Technologies de la Mer, Tunisie, Institut National des Sciences et Technologies de la Mer I.N.S.T.M., Salammbô, Tunis, 128 pp.

James, N.P., Jones, B., 2015. Origin of carbonate sedimentary rocks. American Geophysical Union, 464 p.

Jamila, H., Mouldi, B., Moncef, G., 2016. Assessment of the water quality of Bizerte Lagoon of Tunisia by Use of Statistical Analyses. Hydrology: Current Research 7, 237. doi:10.4172/2157-7587.1000237

Kallel, M.R., 1989. Hydrology of the lagoon of Bizerte. DGRE (Directorate General of Water Resources), Tunis.

Kamens, J., Pilkey, O., Heron, D., Harbridge, W., Keer, F., Thornton, S., 1989. The sedimentology of three Tunisian lagoons. Marine Geology 88, 285-301. doi:10.1016/00253227(89)90102-3

Kamens, J., Pilkey, O., Whalting, P., 1984. Étude sédimentologique des lacs de Bizerte et de Tunis. Notes Serv. Géo. Off. Nat. Min., n 49, pp 5-25.

Khessiba, A., Hoarau, P., Gnassia-Barelli, M., Aïssa, P., Roméo, M., 2001. Biochemical response of the mussel Mytilus galloprovincialis from Bizerta (Tunisia) to chemical pollutant exposure. Archives of Environmental Contamination and Toxicology 40, 222-229.

Lauf, R. J. 2008. Collector's Guide to the Mica Group by Schiffer. Liu, Y., Li, Y., Kang, H., Jin, T., Jiao, L., 2016. Design, synthesis, and energy-related applications of metal sulfides. Matterials Horizons 3, 402-421. doi: 10.1039/C6MH00075D
Martins, M.V.A., Helali, M.A., Zaaboub, N., Boukef-BenOmrane, I., Frontalini, F., Reis, D., Portela, H., Clemente, I.M.M.M., Nogueira, L., Pereira, E., Miranda, P., El Bour, M., Aleya, L., 2016. Organic matter quantity and quality, metals availability and foraminifera assemblages as environmental proxy applied to the Bizerte Lagoon (Tunisia). Marine Pollution Bulletin 105, $161-$ 179. doi.org/10.1016/j.marpolbul.2016.02.032.

Martins, M.V.A. Zaaboub, N., Aleya, L., Frontalini, F., Pareira, E., Miranda, P., Mane, M., Rocha, F., Laut, L., El Bour, M. 2015a. Environmental quality assessment of Bizerte Lagoon (Tunisia) using living foraminifera assemblages and a multiproxy approach. PLoS ONE. doi.10.1371/journal.pone.0137250

Martins, V.A., Silva, F., Lazaro, L.M.L., Frontalini, F., Clemente, I.M., Miranda, P., Figueira, R., Sousa, S.H.M., Dias, J.M.A., 2015b. Response of benthic foraminifera to organic matter quantity and quality and bioavailable concentrations of metals in Aveiro Lagoon (Portugal). PLoS ONE 10 (2): e0118077. doi:10.1371/journal.pone.0118077

Mozley, P.S., Wersin, P., 1992. Isotopic composition of siderite as an indicator of depositional environment. Geology 20, 817-820.

Ouakad, M., 2007. Genèse et évolution des milieux lagunolacustres du Nord-Est de la Tunisie (Garaet el Ichkeul, lagune de Bizerte et de Ghar el Melh). Thèse d'état. Univ. el Manar, Tunis. 461p.

Ouakad, M., 1993. Caractères sédimentologiques et géochimiques des dépôts superficiels de la lagune de Bizerte (Tunisie septentrionale) in circulation des eaux et pollution des côtes méditerranéennes des pays du Maghreb. Edition INOC, Izmir, Turquie, pp 187-194

Ouakad, M., 1982. Etude Sédimentologique et caractères géochimiques des dépôts récents de la Garaet el Ichkeul (Tunisie Septentrionale). Thèse de 3ème Cycle, Université de Perpignan, Perpignan, p.166.

Pettijohn, F.J., Potter P.E., Siever, R., 1987. Sand and Sandstone. Springer Verlag. doi 10.1007/978-1-4612-1066-5

Pollard, P.J., 1989. Geochemistry of Granites Associated with Tantalum and Niobium Mineralization. In Lanthanides, Tantalum and Niobium, Special Publication Volume 7, No. 7, Society for Geology Applied to Mineral Deposits pp 145-168. doi 10.1007/978-3-642-87262-4_5

Riba, I., García-Luque, E., Blasco, J., Del Valls, T.A., 2003. Bioavailability of heavy metals bound to estuarine sediments as a function of $\mathrm{pH}$ and salinity values. Chemical Speciation \& Bioavailability 15,101-114

Roberts, J.A., Kenward, P.A., Fowle, D.A., Goldstein, R.H., Gonzalez, L.A., Moore, D.S., 1980. Surface chemistry allows for abiotic precipitation of dolomite at low temperature. Proceedings of the National Academy of Sciences of the United States of America 110 (36), 14540-14545.

Roger, C., 1955. Données géologiques récentes sur la Tunisie. In: L'information géographique 19 (2), 57-63. doi: 10.3406/ingeo.1955.1467

Romdhane, M.S., Belkhouja, H., 2004. Interaction entre la qualité du substrat et la faune malacologique de la lagune de Bizerte. Final report research promotion program, pp 115-124.

Sakka Hlaili, A., El Grami, B., Niquil, N., Gosselin, M., Hamel, D., Troussellier, M., Hadj Mabrouk, H., 2008. The planktonic food web of the Bizerte Lagoon (southwestern Mediterranean) during summer: I. Spatial distribution under different anthropogenic pressures. Estuarine Coastal Shelf Science 78, 61-77. 
Sakka Hlaili, A., Grami, B., Hadj Mabrouk, H., Gosselin, M., Hamel, D., 2007. Phytoplankton growth and microzooplankton grazing rates in a restricted Mediterranean lagoon (Bizerte Lagoon, Tunisia). Marine Biology 151, 767-783.

Sakka Hlaili, A., Chikhaoui, M.A., El Grami, B., Hadj Mabrouk, H., 2006. Effects of $\mathrm{N}$ and P supply on phytoplankton in Bizerte Lagoon (western Mediterranean). Journal of Experimental Marine Biology and Ecology 333, 79-96.

Sakka Hlaili, A., Chikhaoui, M.A., El Grami, B., Mabrouk, H., 2003. Variation hiverno estivale de la communauté phytoplanctonique de la lagune de Bizerte en milieux naturel et fertilisé en nutriments. Revue de la Faculteé des Sciences de Bizerte, Tunisia, 2, 37-49.

Soussi, N., Levy, A., Zaouali, J., 1983. Lagune de Bizerte: Sédimentologie et écologie des Foraminifères et Mollusques. Notes du Service Géologique de Tunisie, Office National Des Mines, Tunisie, 47, 27-40.

Soussi, N., 1981. Mécanismes de la sédimentation et évolution paléogéographique de la lagune de Bizerte (Tunisie) durant le quaternaire récent. Thèse de Doctorat de Spécialisation Universitaire, Toulouse, 229 p.

Tucker, M.E, 2003, Sedimentary Rocks in the Field: John Wiley and Sons, Chichester.

Tucker, M.E., Wright, V.P., 1990. Carbonate Sedimentology: Blackwell Scientific, Oxford.

Vasconcelos, C., McKenzie, J.A., Bernasconi, S., Grujic, D., Tien, A.J., 1995. Microbial mediation as a possible mechanism for natural dolomite formation at low temperatures. Nature 337 (6546), 220-222. doi:10.1038/377220a0.

Zaaboub, N., Helali, M.A., Martins, M.V.A., 2016. Assessing pollution in a Mediterranean lagoon using acid volatile sulfides and estimations of simultaneously extracted metals. Environmental Science and Pollution Research, 23, 2190821919. doi:10.1007/s11356-016-7431-5

Zaaboub, N., Martins, M.V.A., Béjaoui, A.D.B., Galgani, F., El Bour, M., Aleya, L., 2015. Accumulation of trace metals in sediments in a Mediterranean Lagoon: usefulness of metal sediment fractionation and elutriate toxicity assessment. Environmental Pollution 207, 226-237. doi.org/10.1016/j.envpol.2015.09.03 